\author{
RESEARCH ARTICLE \\ 10.1029/2018JF004837 \\ Key Points: \\ - We use a numerical model to \\ fingerprint the sediment that \\ contributed to debris flows during a \\ sequence of postfire rainstorms \\ - Both gradual entrainment and \\ mass failure of the channel bed can \\ increase sediment concentrations to \\ levels associated with debris flows \\ - Postwildfire debris-flow initiation \\ seems closely linked to rainfall \\ intensity despite temporal changes in \\ sediment source and initiation style
}

Supporting Information:

- Supporting Information S1

- Video S1

Correspondence to:

H. Tang,

huitang@email.arizona.edu

Citation:

Tang, H., McGuire, L. A.,

Rengers, F. K., Kean, J. W.,

Staley, D. M., \& Smith, J. B. (2019).

Evolution of debris-flow initiation

mechanisms and sediment sources during a sequence of postwildfire rainstorms. Journal of Geophysical Research: Earth Surface, 124,

1572-1595. https://doi.org/10.1029/ 2018JF004837

Received 9 AUG 2018

Accepted 19 APR 2019

Accepted article online 6 MAY 2019

Published online 26 JUN 2019
Published 2019. This article is a U.S. Government work and is in the public domain in the USA.

\section{Evolution of Debris-Flow Initiation Mechanisms and Sediment Sources During a Sequence of Postwildfire Rainstorms}

\author{
Hui Tang1 ${ }^{(\mathbb{D})}$, Luke A. McGuire ${ }^{1}(\mathbb{D})$, Francis K. Rengers ${ }^{2}\left(\mathbb{D}\right.$, Jason W. Kean ${ }^{2}(\mathbb{D}$, \\ Dennis M. Staley², and Joel B. Smith² \\ ${ }^{1}$ Department of Geosciences, University of Arizona, Tucson, AZ, USA, ${ }^{2}$ U.S. Geological Survey, Golden, CO, USA
}

\begin{abstract}
Wildfire alters vegetation cover and soil hydrologic properties, substantially increasing the likelihood of debris flows in steep watersheds. Our understanding of initiation mechanisms of postwildfire debris flows is limited, in part, by a lack of direct observations and measurements. In particular, there is a need to understand temporal variations in debris-flow likelihood following wildfire and how those variations relate to wildfire-induced hydrologic and geomorphic changes. In this study, we use a combination of in situ measurements, hydrologic monitoring equipment, and numerical modeling to assess the impact of wildfire-induced hydrologic and geomorphic changes on debris-flow initiation during seven postwildfire rainstorms. We predict the impact of hillslope erosion on debris-flow initiation by combining terrestrial laser scanning surveys of a hillslope burned during the 2016 Fish Fire with numerical modeling of sediment transport throughout a $0.12-\mathrm{km}^{2}$ basin in southern California. We use measurements of sediment thickness within the channel to constrain numerical experiments and to assess the role of channel sediment supply on debris-flow initiation. Results demonstrate that debris flows initiated during rainstorms where hillslopes contributed minimally to the event sediment yield and suggest that large inputs of sediment from rill and gully networks are not essential for runoff-generated debris flows. Simulations suggest that both the gradual entrainment of sediment and the mass failure of channel bed sediment can increase sediment concentration to levels associated with debris flows. Finally, postwildfire debris-flow initiation appears closely linked to the same rainfall intensity-duration threshold despite temporal changes in the sediment source, initiation processes, and hydraulic roughness.
\end{abstract}

\section{Introduction}

The size and frequency of wildfires have been increasing throughout the western United States since the mid-1980s (Westerling et al., 2006). Postwildfire hazards, including debris flows, therefore continue to be problematic as populations expand into mountainous areas susceptible to these risks (Cannon \& DeGraff, 2009). Postwildfire debris flows are often generated by runoff, which differentiates them from those that are mobilized from shallow landslides. Wildfire significantly increases the likelihood of runoff-generated debris flows (Cannon, 2001a; Cannon \& DeGraff, 2009; Shakesby \& Doerr, 2006; Staley et al., 2014) by altering vegetation and soil properties (Ebel \& Moody, 2017; Moody et al., 2005) in ways that promote increased runoff and sediment transport. The risks posed by postwildfire debris flows necessitate an improved understanding of the mechanisms through which debris flows initiate. In particular, there is a need to quantify the physical location of source material for debris flows in steep, recently burned catchments (e.g., Staley et al., 2014) and to ascertain the processes through which that sediment is incorporated into debris flows (e.g., Santi et al., 2008). Identifying the sediment sources and hydrogeomorphic conditions associated with debris-flow initiation will (1) help to shed light on the climatic and geologic factors underlying regional differences in the rainfall intensities (e.g., Staley et al., 2017) required to generate postwildfire debris flows and (2) will improve our ability to anticipate debris-flow hazards throughout the postwildfire recovery process, as sediment supplies diminish and soil hydrology recovers.

Following a wildfire, there is often an abundant source of sediment in both channels and hillslopes that could potentially be mobilized into a debris flow. On steep hillslopes that are common in the San Gabriel Mountains, vegetation can hold sediment on hillslopes in small dams that form upslope of stems. Once the vegetation is incinerated during the wildfire, this sediment is released downslope (Florsheim et al., 1991; 
Lamb et al., 2011). Extensive deposits from dry ravel following wildfire are not unique to the Transverse Ranges of southern California (e.g., Cannon et al., 2001; Roering \& Gerber, 2005) and may generally provide an abundant source of sediment to channels that can later be mobilized into debris flows. Indeed, studies conducted in the western United States highlight the importance of channel sediment in contributing to postwildfire sediment yields (Moody \& Martin, 2009) and the sediment in debris flows, with Santi et al. (2008) concluding that the material for postfire debris flows came predominantly from the main channel in 46 debris-flow-producing basins. In their study of postwildfire debris flows in Victoria, Australia, Smith et al. (2012) found that hillslopes contributed between $22 \%$ and $74 \%$ of the fine material in postfire debris-flow deposits based on the distribution of fallout radionuclides. Staley et al. (2014) determined that hillslopes contributed to the majority of sediment eroded during a debris-flow-producing storm in the San Gabriel Mountains following the 2009 Station Fire. In addition to determining the physical location of dominant sediment sources in postwildfire landscapes, identifying the fate of eroded sediment (e.g., does it contribute to debris-flow initiation) may help shed light on debris-flow initiation processes. For instance, the majority of erosion during a debris-flow-producing rainstorm may come from the hillslopes, but this does not necessarily mean that hillslope erosion played a role in initiating the observed debris flow or that the majority of sediment in the debris flow was derived from hillslopes.

Previous studies throughout the western United States suggest that rilling may be the dominant form of erosion on burned hillslopes (Cannon et al., 2001b; Istanbulluoglu et al., 2003; Robichaud et al., 2010; Schmidt et al., 2011). Rilling may play a critical role in postwildfire debris-flow initiation by supplying an abundance of fine sediment to the channel network (Meyer \& Wells, 1997). Wells and Wade (1987) described rill incision as one of two wildfire-enhanced erosion processes (the other being dry ravel) responsible for debris-flow initiation in the steep mountains of southern California. Cannon et al. (2001b) found that debris flows initiated high on hillslopes within the rill network based on observations of levee-lined rills at the Cerro Grande Fire, New Mexico. Other studies focused on the initiation of runoff-generated debris flows also highlight observations of levee-lined rills (e.g., Langhans et al., 2017; Nyman et al., 2011), further suggesting that rill erosion plays a role in achieving the high sediment concentrations required for debris flows. Several recent studies, however, using high-resolution digital elevation models (DEMs) derived from terrestrial laser scanner (TLS) surveys, suggest that erosion from interrill areas may contribute to the majority of erosion on steep, recently burned hillslopes (e.g., Rengers et al., 2016; Staley et al., 2014). Despite intense rilling within their study area, Staley et al. (2014) used repeat TLS surveys to determine that, during a storm that produced multiple debris flows, roughly $57 \%$ of erosion from their $0.01-\mathrm{km}^{2}$ study area occurred on divergent hillslope locations. Rill erosion, while often more visible and readily observed, may play a smaller role relative to interrill erosion in supplying fine sediment to the channel network during some debris-flow-producing storms. Since the effectiveness of sediment transport within rill and interrill areas can be affected differently by distinct wildfire-induced changes (e.g., percent bare ground, infiltration capacity, and hydraulic roughness), determining where sediment originates and how it is initially mobilized (e.g., in rill or interill areas) can aid in assessing changes in debris flow potential as a function of soil and vegetation recovery.

It has been difficult to infer specifics of the hydrologic and geomorphic processes that give rise to postwildfire debris flows, in part, because the precise initiation location of runoff-generated debris flows in burned areas is almost always unknown. In contrast, debris flows that mobilize from shallow landslides (Iverson et al., 1997; Gabet \& Mudd, 2006; Germer \& Braun, 2011) often leave behind identifiable scarps at their initiation locations. Several mechanistic explanations for the transition from clear water runoff to a debris flow have been offered, including progressive (grain-by-grain) sediment bulking (Cannon, 2001a; Cannon et al., 2001, 2001b; Meyer \& Wells, 1997), the mass failure of channel bed sediment (Kean et al., 2013; Takahashi, 1978, 1981), the fire hose effect (i.e., runoff pouring over a cliff onto unconsolidated sediment; Arattano \& Marchi, 2000; Melis et al., 1994), and bank failure (Berti \& Simoni, 2005). Cannon (2001a) demonstrated that a sediment bulking process could generate postwildfire debris flows based on detailed field observations and aerial photographs. Based on observations from Chalk Cliffs in Colorado and Arroyo Seco in southern Califonia, Kean et al. (2013) argued that low-gradient sections in the channel network could temporarily store sediment transported by water-dominated flows, allowing it to build up until a critical condition for failure is met. Debris flows then form periodically following the mass failure of this channel bed sediment. Recently, McGuire et al. (2017) used a combination of debris-flow monitoring data and numerical modeling to demonstrate that debris-flow initiation within a $0.01-\mathrm{km}^{2}$ basin burned by the 2009 Station Fire was most consistent with initiation via the mass failure of channel bed sediment. We extend this previous work 


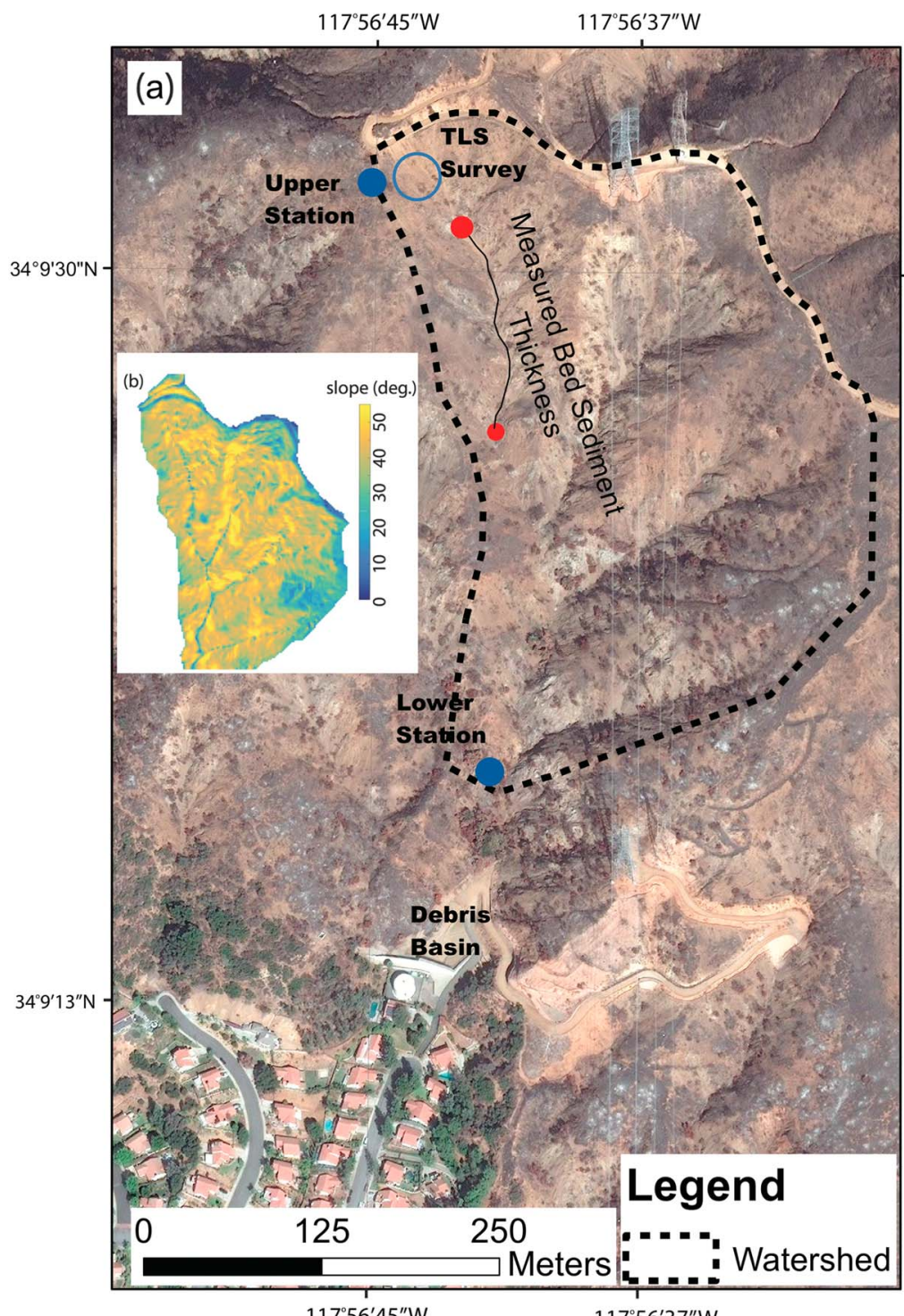

$117^{\circ} 56^{\prime} 45^{\prime \prime} \mathrm{W}$
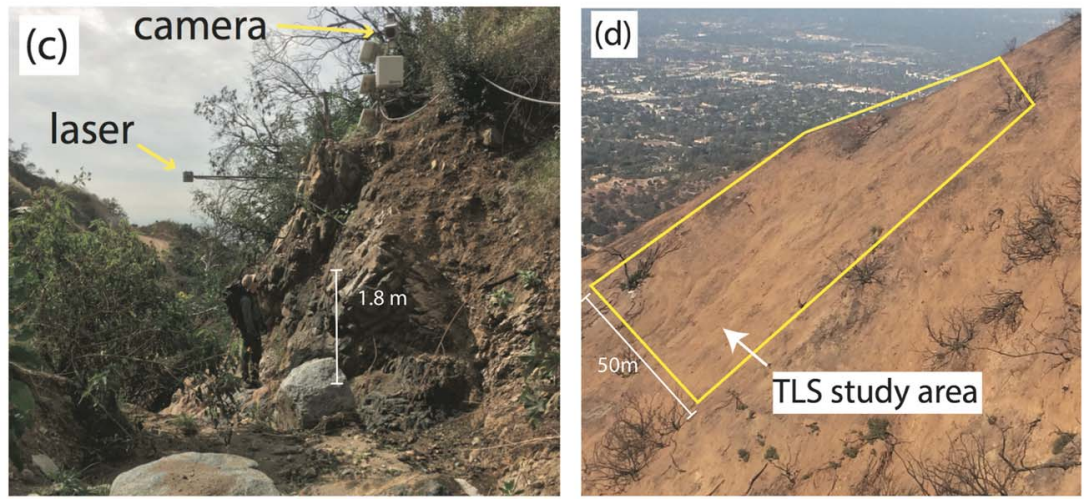

Figure 1. The study site is located in the San Gabriel Mountains near Duarte, California, USA, and was burned during the 2016 Fish Fire: (a) Location of the study site within the burn area of the 2016 Fish Fire; (b) topographic slopes are particularly steep and regularly exceed $30^{\circ}$ on the hillslopes; (c) a photograph of the lower monitoring station at our study site; (d) a picture taken in November 2016 shows the lack of vegetation in the terrestrial laser scanning (TLS) survey area. 
by using the numerical model developed by McGuire et al. (2017) to isolate the mechanism(s) that led to debris-flow initiation throughout a series of seven different rainstorms, with an added focus on assessing how temporal changes in sediment sources and sediment supply affect the initiation process.

The numerical model is applied to study erosion and debris-flow initiation within a $0.12-\mathrm{km}^{2}$ drainage basin in the San Gabriel Mountains near Duarte, California, USA, which burned during the 2016 Fish Fire. The study area was intensively monitored after the fire to obtain detailed measurements of topographic change and hydrological data. After the wildfire, monitoring equipment at the basin outlet recorded seven rainstorms that produced runoff and/or debris flows. Repeat TLS data provide controls on the magnitude of hillslope erosion, which are used to calibrate sediment transport parameters within the model, and measurements of channel bed sediment thickness constrain changes in the sediment supply within the channel network. This study focuses on the two storms with the highest rainfall intensity after the fire, which also correspond to the first and last rainstorms during the first year of postfire monitoring, because large differences in channel sediment supply and hydraulic roughness were observed between these two events. However, we do summarize modeling results from all seven runoff-producing rainstorms during the monitoring period. By simulating runoff and sediment transport throughout the drainage basin for each of the seven monitored rainstorms, we are able to determine the provenance of sediment that ultimately mobilized into a debris flow. In addition to isolating the physical location of sediment that contributes to debris flows at our site, we also use the model to determine the sediment transport mechanisms responsible for mobilizing the sediment needed to produce debris flows. We refer to this process as "fingerprinting" the sediment that generates debris flows. Although we do not track individual particles throughout the transport process, the model can be employed to determine, for example, whether or not debris flows would form in the absence of raindrop-driven sediment detachment. Finally, we evaluate the importance of sediment supply within the channel network by comparing results of simulations for three different conditions, where the channel contained either (1) dry ravel deposits (recently deposited, cohesionless sediment), (2) original soil (cohesive sediment), or (3) no sediment (i.e., a bare bedrock channel).

\section{Study Area}

The study area consists of a $0.12-\mathrm{km}^{2}$ drainage basin at the base of the San Gabriel Mountains, California, USA. It is part of a larger, $0.2-\mathrm{km}^{2}$ watershed that drains into the Las Lomas debris basin (Figure 1). Chaparral is the dominant vegetation type in the area, but the basin was burned at moderate-to-high severity during the Fish Fire in the summer of 2016, leaving behind only remnants of charred, woody vegetation throughout most of the site. Some vegetation survived near the channel at the lowest portions of the basin (Figures 1a and 1c). Rainfall interception processes are limited for all storms after the fire since there was little vegetation remaining and regrowth during the time of the study was minimal. Slopes in the study area are steep and have a mean hillslope angle of $38^{\circ}$ (Figure 1b). Based on field observations and grain-size analyses, sediment in the hillslope is a fine sandy loam. Dry ravel deposits, which generally consisted of coarser sediment relative to the hillslopes, covered the majority of the surface area within the channel network before the first rainstorm (Figure S1 in the supporting information).

A $900-\mathrm{m}^{2}$ subbasin, located on a steep hillslope near the upper boundary of the study area, was selected for repeat TLS surveys (Figures 1a and 1d). This particular site was identified because local burn severity appeared representative of other hillslopes within the study area. Loose, dry ravel deposits filled in many areas within the scan area that had locally lower slopes, including a zone several meters wide extending upslope from the base of the TLS area. Saprolite was exposed on the steepest portions of hillslopes throughout the study site, including the TLS area, after the wildfire and subsequent erosion by dry ravel.

\section{Methods}

\subsection{Numerical Model}

The numerical model, which is described in detail by McGuire et al. (2016, 2017), consists of five major components: infiltration, rainfall interception, fluid flow, size-selective sediment transport, and mass failure of bed material. Here, we only review key pieces of the model that are most relevant to this study. Water flow and sediment transport within multiple particle-size classes are modeled using the two-dimensional, nonlinear shallow water equations coupled with a set of advection equations used to track the movement 
of sediment in each particle-size class. Additional source terms related to debris-flow resistance, following Iverson and Denlinger (2001), are included within the momentum equations (McGuire et al., 2016). Debris flows are identified within the model solution based on the volumetric sediment concentration $\left(c_{*}\right)$ and flow depth ( $h$; McGuire et al., 2016). If the flow depth exceeds $10 \mathrm{~cm}$, and the volumetric sediment concentration is greater than $40 \%$, then the flow is considered as a debris flow (McGuire et al., 2016). Infiltration is represented using the Green-Ampt equation (Green \& Ampt, 1911). In this study, the rainfall intensity is interpolated based on field measurement from two stations for the entire study area.

The Hairsine-Rose soil erosion model is used to simulate sediment detachment by both raindrop impact, which is often a dominant form of particle detachment in shallow interrill zones, and flow-driven processes, which become dominant in areas of concentrated overland flow in unchannelized areas (Hairsine \& Rose, 1991, 1992a, 1992b). Once detached, sediment can be transported and deposited. The mass of deposited sediment is tracked at every point in the computational domain and has detachability properties that differ from the underlying soil (Hairsine \& Rose, 1991, 1992a, 1992b). Sediment in the deposited layer is more easily detached but also shields the underlying soil from flow- and raindrop-driven detachment processes. The model's ability to distinguish between flow-driven and raindrop-driven detachment is crucial for being able to ascertain the origin of debris-flow sediment. For example, we take advantage of the explicit representation of flow-driven and raindrop-driven processes within the model framework to determine the relative importance of these two mechanisms in transporting the sediment that ultimately contributes to observed debris flows.

Letting $h, u$, and $v$ denote flow depth and depth-averaged velocities in the $x$ and $y$ directions, respectively, the Hairsine-Rose equations for sediment size class $k$ are

$$
\begin{gathered}
\frac{\partial\left(h c_{k}\right)}{\partial t}+\frac{\partial\left(h c_{k} u\right)}{\partial x}+\frac{\partial\left(h c_{k} v\right)}{\partial y}=e_{k}+e_{r k}+r_{k}+r_{r k}-d_{k}, \\
\frac{\partial\left(m_{k}\right)}{\partial t}=d_{k}-e_{k}-r_{r k},
\end{gathered}
$$

where $c_{k}$ is the sediment concentration of sediment size class $k, m_{k}$ is the deposited sediment mass for sediment size class $k$ per unit area, $r_{k}$ and $r_{r k}$ denote rates of entrainment and reentrainment due to runoff, and $e_{k}$ and $e_{r k}$ denote the rates of raindrop-driven detachment and redetachment. The deposition rate, $d_{k}$, for sediment size class $k$ is a function of the clear water settling velocity and the total sediment concentration (McGuire et al., 2016). Letting $a$ and $a_{d}$ denote raindrop detachment and redetachment coefficients, the rates of raindrop-driven detachment $\left(e_{k}\right)$ and redetachment $\left(e_{r k}\right)$ are given by

$$
\begin{gathered}
e_{k}=(1-H) p_{k} a P\left(\left(1-C_{v}\right)+T_{c} C_{v}\right) T_{c}, \\
e_{r k}=H \frac{m_{k}}{m_{t}} a_{d} P\left(\left(1-C_{v}\right)+T_{c} C_{v}\right),
\end{gathered}
$$

where $H=\min \left(m_{t} / m_{t}^{*}, 1\right)$ is the degree to which deposited sediment shields the underlying soil from erosion, $m_{t}^{*}$ is the mass of deposited sediment needed to completely shield the original soil from erosion processes, $p_{k}$ represents the proportion of the original soil in sediment size class $k, P$ represents rainfall intensity, $C_{v}$ is the percentage of vegetation cover, $T_{c}$ is the throughfall coefficient, and $m_{t}$ is the total deposited sediment mass per unit area. The raindrop detachment and redetachment coefficients, $a$ and $a_{d}$, decrease with flow depth according to

$$
\begin{gathered}
a=\left\{\begin{array}{ll}
a_{0} & h^{\prime}<h_{0} \\
a_{0}\left(h_{0} / h^{\prime}\right)^{b} & h^{\prime} \geq h_{0}
\end{array},\right. \\
a_{d}=\left\{\begin{array}{ll}
a_{d 0} & h^{\prime}<h_{0} \\
a_{d 0}\left(h_{0} / h^{\prime}\right)^{b} & h^{\prime} \geq h_{0}
\end{array},\right.
\end{gathered}
$$

where $h_{0}=d_{r} / 3$ is a critical depth of overland flow over which the influence of raindrop impact is assumed to decay, $d_{r}$ denotes the median raindrop diameter, $b=1$ is an empirical coefficient, $h^{\prime}=h / \cos \theta_{t}$ is the 
flow depth measured vertically from the soil surface, and $\theta_{t}$ is the topographic slope angle. The mass of deposited sediment required to shield the original soil completely also decreases with increasing flow depth (see McGuire et al., 2016).

Rates of entrainment and reentrainment due to runoff, $r_{k}$ and $r_{r k}$, are given by

$$
\begin{gathered}
r_{k}=(1-H) p_{k} \frac{F\left(\Omega-\Omega_{c r}\right)}{J}, \\
r_{r k}=(1-\beta) H \frac{m_{k}}{m_{t}} \frac{F\left(\Omega-\Omega_{c r}\right)}{\frac{\rho_{s}-\rho_{w}}{\rho_{s}} g h},
\end{gathered}
$$

where $\Omega=\rho g h S_{f}$ denotes stream power; $S_{f}=n^{2}\left(u h^{2}+v h^{2}\right) h^{-10 / 3}$ is the friction slope; $F$ is the fraction of excess stream power effective in entrainment; $\Omega_{c r}$ is the slope-dependent critical stream power needed for entrainment as given by Ferguson (2012); $\rho_{w}, \rho_{s}$, and $\rho$ are the densities of water, sediment, and water-sediment mixture, respectively; and $J$ is the energy required per unit mass of sediment for entrainment. The variable $J$ can be related to the detachability of original soil $\left(a_{0}\right)$ and raindrop impact velocity $\left(v_{r}\right)$ through the relationship $J=\frac{0.5 \rho_{w} v_{r}^{2}}{a_{0}}$ (Heng et al., 2011). The parameter $\beta$ is fraction of excess stream power effective in bed load transport. Hydraulic roughness is taken into account using a depth-dependent Manning coefficient proposed by Jain et al. (2005),

$$
n= \begin{cases}n_{0}\left(h / h_{c}\right)^{-\epsilon} & h<h_{c} \\ n_{0} & h \geq h_{c}\end{cases}
$$

where $n_{0}$ is minimum Manning coefficient, $\epsilon$ is a positive exponent, and $h_{c}$ denotes critical depth associated with friction.

The mass failure of bed sediment occurs whenever the driving forces exceed the resisting forces in the deposited sediment layer. When the deposited sediment layer is stable, the balance of force in the $x$ direction can be written as

$$
\left(\rho_{s} g h_{s} \cos \theta+\rho_{w} g h \cos \theta-p_{b e d}\right) \tan \phi_{b e d}+h_{s} \frac{\partial}{\partial x}\left(\rho_{s} g h_{s} \cos \theta\right)+C=\left(\rho_{s} h_{s}+\rho_{w} h\right) g \sin \theta,
$$

where $\theta$ denotes the bed angle, $h_{s}$ and $h$ represent the depth of the deposited sediment layer and overland flow depth, $\phi_{b e d}$ is the static angle of friction for sediment, $C$ is effective cohesion, and $p_{b e d}=\rho_{w} g\left(h+h_{s}\right)$ is basal pore pressure equal to the hydrostatic pressure. The left-hand side of the equation includes terms associated with the friction, normal stress, and cohesion. The right-hand side of the equation accounts for the driving force from the downslope component of the weight of sediment and water. Failure is only allowed to occur at the interface between the deposited sediment layer and the original soil (or bedrock) after the sediment layer is fully saturated by water (McGuire et al., 2017). When a failure occurs at a given location, all sediment is removed from the deposited sediment layer and added to the flow. We neglect bed failure in the original soil because we assume that it is more cohesive. However, the model can be initialized with a prescribed amount of sediment in the deposited layer if needed. Here, we begin simulations with a nonzero amount of deposited sediment in the channel network based on the field-measured thickness of dry ravel deposits within the channel.

\subsection{TLS Surveys}

Repeat TLS-derived DEMs document the magnitude and spatial patterns of erosion associated with rainstorms within a subbasin at our study site (Figure 1d; McGuire \& Rengers, 2019). All TLS surveys were completed with a Leica ScanStation C10. The Leica ScanStation C10 has an accuracy of approximately $6 \mathrm{~mm}$ and a range of up to $300 \mathrm{~m}$. During each survey, the scanner was set up on a tripod at seven to eight different scan positions around the exterior boundary of the subbasin. Scanning from multiple positions helps to reduce shadowing effects created by vegetation or undulations in topography that may obscure the ground surface from view at one or more of the scan positions. The first TLS survey was performed on 19 November 2016 before the first postfire rainstorm. The second survey was conducted on 5 January 2017, after the second rainstorm. 

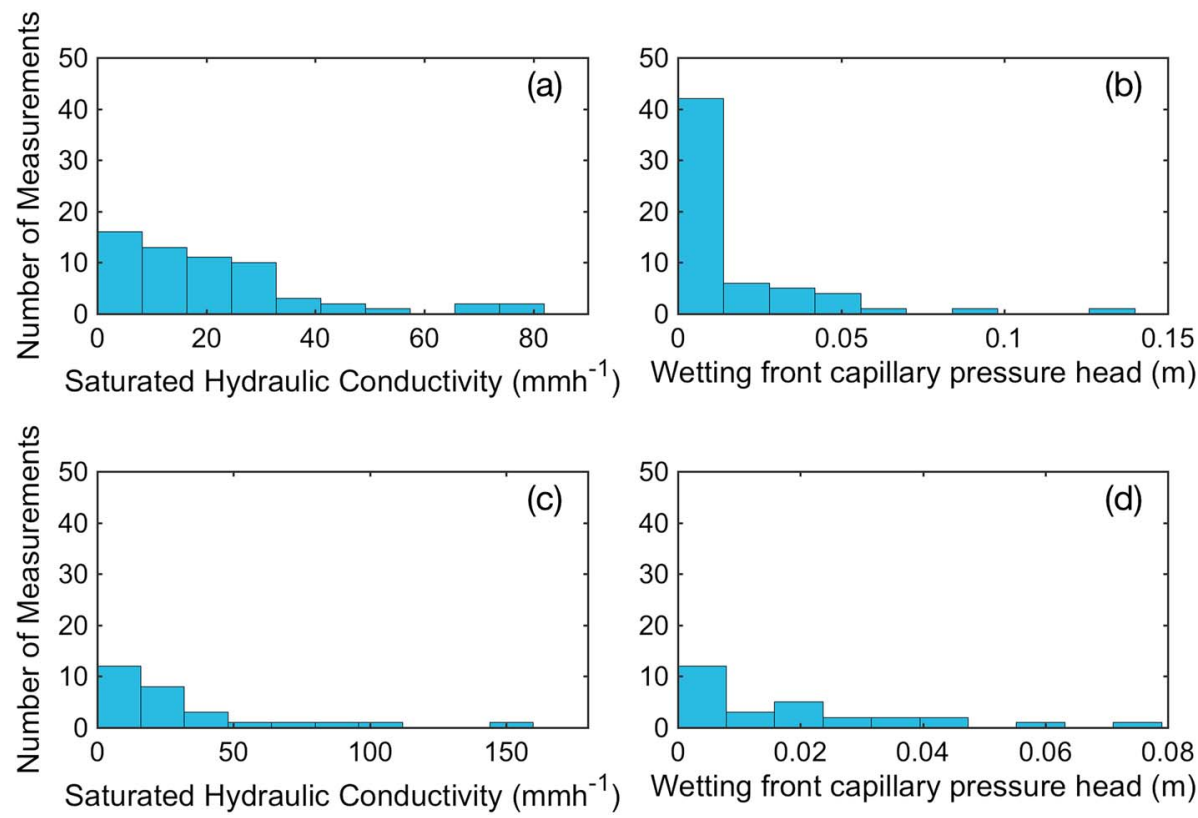

Figure 2. Measurements of saturated hydraulic conductivity $\left(K_{s}\right)$ made using a mini disk infiltrometer between (a) September and November 2016 and in (c) January 2017. The wetting front capillary pressure head $\left(h_{f}\right)$ for (b) September-November 2016 and (d) January 2017 were derived from measurements of saturated hydraulic conductivity $\left(K_{S}\right)$ and sorptivity $(S)$.

Two high-intensity rainstorms impacted the study site between the first and second TLS surveys while there were five runoff-generating rainstorms after the second surveys during monitoring period. By differencing the TLS-derived DEMs that bracket the first two rainstorms, we determined the volume of sediment eroded from both rill and interrill areas. Error estimates for the volume eroded area are based on multiplying the area (of either the rill or interrill zone) by the error associated with the elevation uncertainty in the DEMs. The elevation uncertainty was calculated as $\delta=\sqrt{\sigma_{r}^{2}+\sigma_{s}^{2}}$, where $\sigma_{r}=0.002 \mathrm{~m}$ is the registration error and $\sigma_{s}=0.006 \mathrm{~m}$ is the accuracy of the scanner, which results in an uncertainty of $\delta=0.0063 \mathrm{~m}$.

The original resolution for the TLS-derived DEMs is $0.025 \mathrm{~m}$, but the grid spacing was increased to $0.4 \mathrm{~m}$ to improve the computational efficiency of the model. A 3-m resolution DEM derived from prefire airborne lidar, which covers the entire study basin, was interpolated to a 1-m grid for simulations at the basin scale. Since grid resolution can influence the degree to which water concentrates into preferential flow pathways, the use of a 1-m grid was selected as a compromise that allowed for reasonable simulation times while also minimizing differences in grid resolution between the TLS-generated DEM and the airborne-lidar-derived DEM (Rengers et al., 2016).

\subsection{Field Measurements}

After the wildfire, sediment deposited within the channel through dry ravel may play a critical role in supplying sediment for debris flows (Lamb et al., 2011, 2013). Field measurements of ravel deposit thickness were conducted three different times throughout the study period by driving a 1-m piece of rebar into the channel sediment. Measurements of deposit thickness were restricted to a 150-m channel reach due to an active bear den downstream. Measurements were made on 9 November 2016, 4 January 2017, and 22 February 2017 (Figure 1a). Samples for ravel deposits and fine sediment on hillslope area were collected and analyzed to determine grain-size distributions and basal friction angles. The $D_{50}$ of sediment in ravel deposits and hillslope soil are 0.806 and $0.219 \mathrm{~mm}$, respectively. The basal friction angle of sediment in the ravel deposits was estimated at $34^{\circ}$ based on torsional ring shear tests.

Saturated hydraulic conductivity $\left(K_{s}\right)$ and wetting front capillary pressure head $\left(h_{f}\right)$, which are key input parameters of the Green-Ampt infiltration model, were constrained from in situ field measurements. Infiltration measurements were made during site visits in November, December, January, and February on 1-m intervals along a 20-m transect located adjacent to the TLS survey area using a Decagon mini disk portable tension infiltrometer with a suction of $1 \mathrm{~cm}$. Additional infiltration measurements were made nearby, in the 

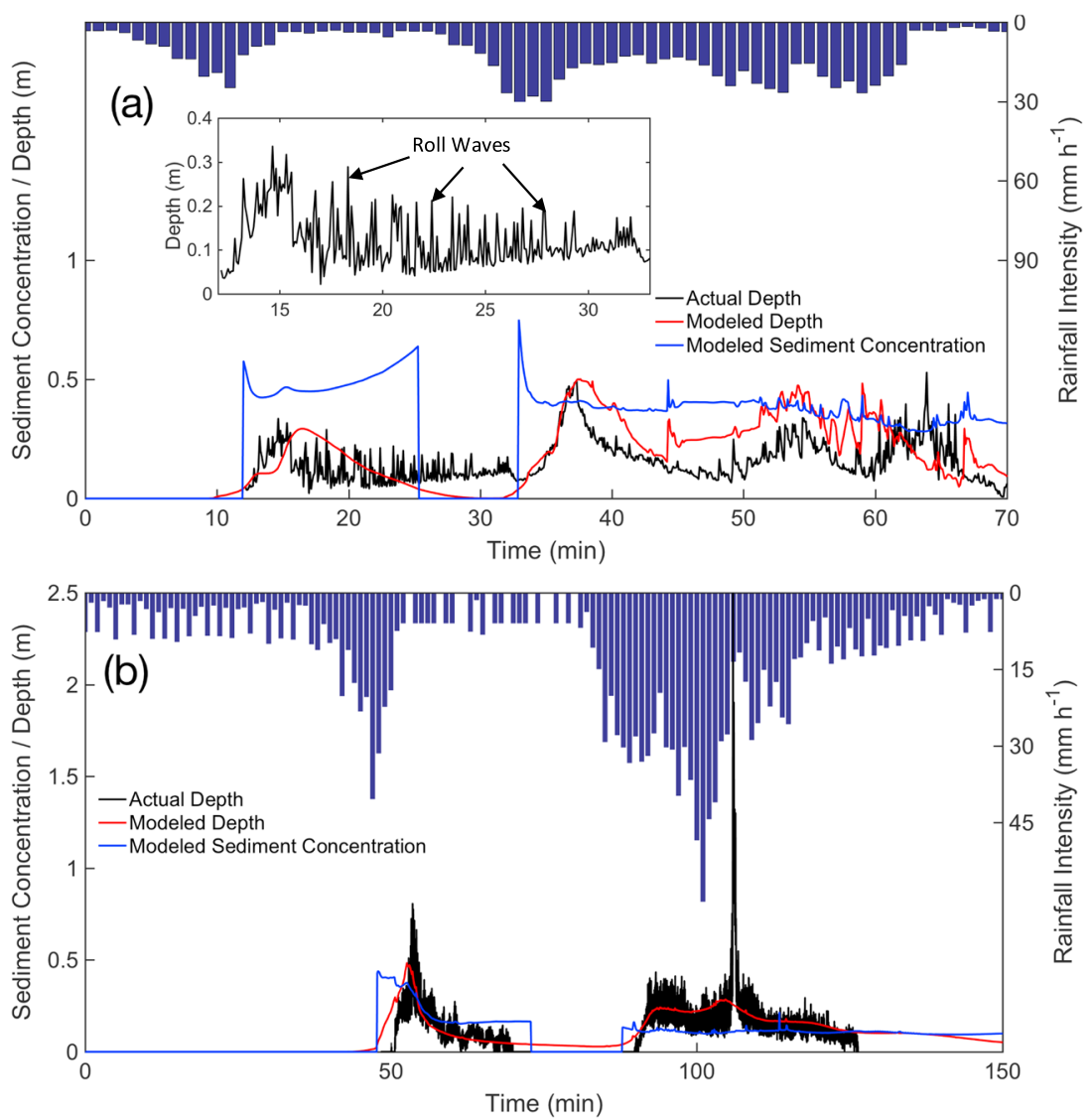

Figure 3. One-minute average rainfall intensity, actual hydrograph, model-simulated hydrograph, and sediment concentration using the best fit calibrated parameters for storms on 16 December 2016 and 18 February 2017: (a) comparison of the modeled and actual hydrographs for the storm on 16 December 2016. Time starts at 11:00 am local time on 16 December 2016. The observed stage at the outlet of the basin is highly variable and consists of a sequence of roll waves followed by three periods of debris flow triggered by peaks in rainfall intensity. (b) Comparison of the modeled and actual hydrograph for the storm on 18 February 2017. Observations indicated three periods of debris flow, but the model simulates only one period where flow concentration exceeds 40\%. Time starts at 01:00 am local time on 18 February 2017.

area surrounding the TLS site, as time permitted. The volume of water infiltrated as a function of time was recorded and analyzed following the methodology of Zhang (1997) and Vandervaere et al. (2000) to obtain the field-saturated hydraulic conductivity $\left(K_{s}\right)$ and sorptivity $(S)$. Zhang (1997) demonstrated that the volume of water infiltrated could be related to time, sorptivity, and the field-saturated hydraulic conductivity through the relationship $I=C_{1} \sqrt{t}+C_{2} t$ where $C_{1}=A_{1} S, C_{2}=A_{2} K_{s}$, and $A_{1} \approx 1$ and $A_{2}$ are empirical coefficients that are functions of soil texture. We employ the three-curve fitting techniques suggested by Vandervaere et al. (2000) to determine $K_{S}$ and $S$ based on the above relationships. This yields three estimates of field saturated hydraulic conductivity and sorptivity for each infiltration measurement, which we average to obtain one final value for each. The wetting-front capillary pressure head $\left(h_{f}\right)$ is then given by $h_{f}=S^{2} /\left(2 K_{s} \theta_{s}\right)$ (Ebel \& Moody, 2017), where $\theta_{s}=0.4$ is the soil moisture at saturation.

A total of 61 infiltration measurements were made between the wildfire and the first rainstorm on 16 December 2016. Another 28 measurements were made during January 2017, resulting in a total of 89 measurements prior to the last storm during the monitoring period. Since soil hydrologic properties did not appear to change substantially throughout the study period, results of all 89 measurements were lumped together for integration into the numerical model (Figure 2). The $K_{s}$ and $h_{f}$ values within the model domain were assigned on a cell-by-cell basis by randomly selecting values from a distribution fit to these 89 measured values by empirical cumulative distribution function. We further assumed, based on field observations of exposed bedrock in steeper portions of the study area, that locations with a slope over $45^{\circ}$ were not soil-mantled (DiBiase et al., 2017). 

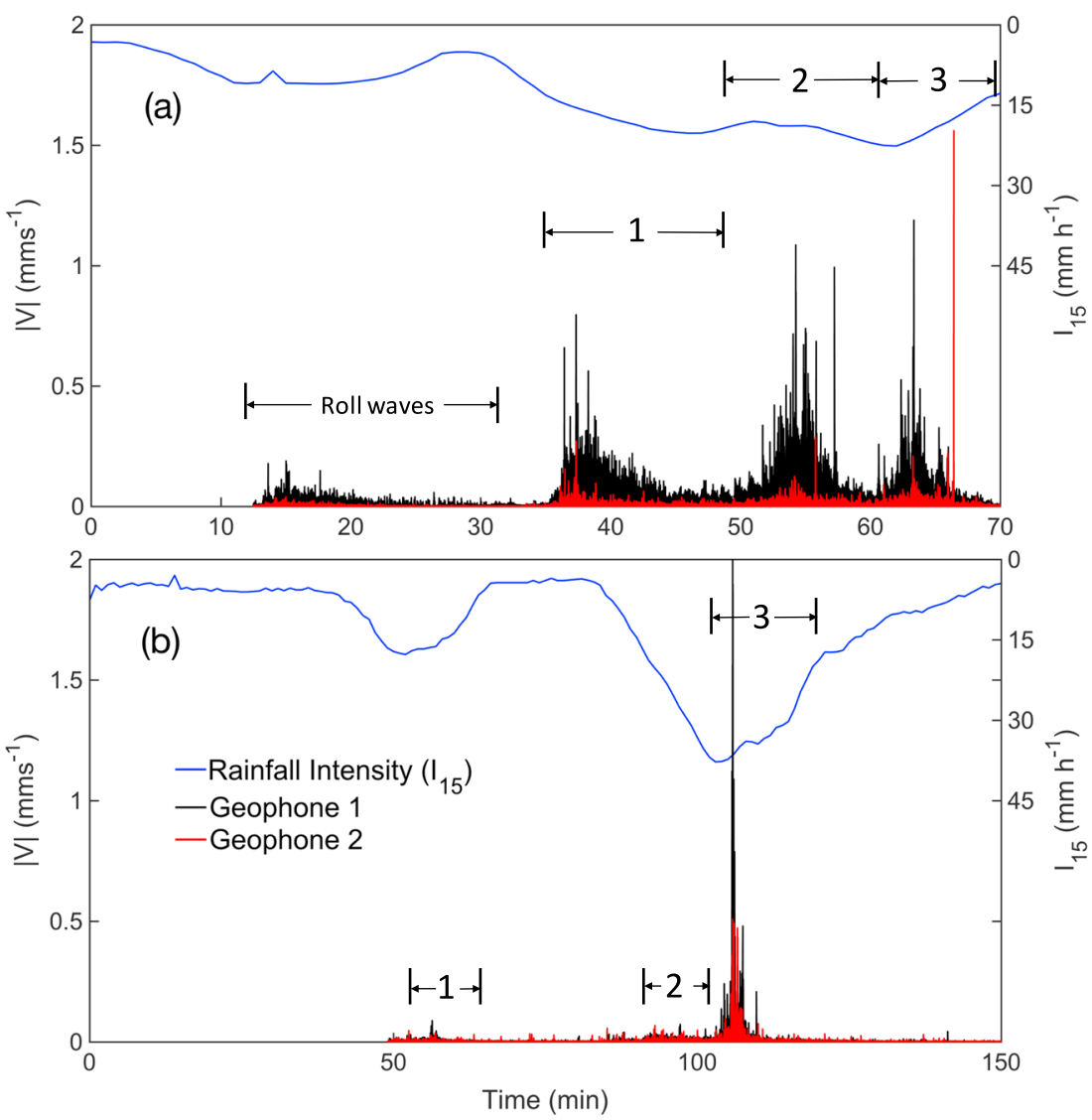

Figure 4. Ground motion velocity from two geophones and rainfall intensity $I_{15}$ during rainstorms with runoff: (a) 16 December 2016 and (b) 18 February 2017. Time in (a) is in minutes after 11:00 am 16 December 2016 and in (b) is in minutes after 01:00 am 18 February 2017. Three identified periods of debris-flow occurrence (labeled as 1, 2, and 3 in (a) and (b)) generally correspond with a threshold ground velocity greater than $0.1 \mathrm{~mm} / \mathrm{s}$ in both storms. Note that $|V|>0.1 \mathrm{~mm} / \mathrm{s}$ at the start of the first storm due to the passage of a series of roll waves.

\subsection{Hydrological Monitoring}

Two tipping bucket rain gages and one disdrometer recorded rainfall at the study site. The disdrometer was located adjacent to the TLS survey site (Figure 1a), along with one of the rain gages. The second tipping bucket rain gage was installed at the basin outlet as part of the lower station (Figure 1a). We computed the average rainfall intensity over 1- and 15-min intervals based on data from the disdrometer and the tipping bucket rain gage located at the channel monitoring station (Figures 3 and 4). The disdrometer also measured the median raindrop diameter as well as raindrop impact velocity, which are both input parameters in the Hairsine-Rose soil erosion model.

The channel monitoring station included a second rain gage, two geophones, a rain-triggered video camera, and a laser distance meter. The flow stage was measured by a laser distance meter with $50-\mathrm{Hz}$ sample frequency suspended over the channel near the outlet of the study basin, as described in more detail by Kean et al. (2011). Due to erosion and deposition during storms, however, the thickness of stationary bed sediment beneath the flow is not known precisely as a function of time. Therefore, the true flow depth with respect to the channel bottom is uncertain. Following Kean et al. (2011), we estimated flow depth by linearly interpolating the channel bottom elevation between periods of active flow (Figure 3).

The geophones, which were sampled at a frequency of $50 \mathrm{~Hz}$, were installed 6.4-m upstream and 7.6-m downstream of the monitoring station. Geophones are well suited to monitoring debris-flow activity since they record the increase in ground vibrations that accompanies most debris-flow surges (Arattano \& Marchi, 2005; Suwa et al., 2009). The rain-triggered video camera located at the channel monitoring station provides additional qualitative information on flow magnitude and timing as well as information about flow type (i.e., debris flow or flood). In this study, we used video evidence and a threshold ground velocity of $0.1 \mathrm{~mm} / \mathrm{s}$, as 
Table 1

Model Parameter Values Used in Numerical Simulations of Runoff and Sediment Transport

\begin{tabular}{lcccc}
\hline Symbol & Unit & Definition & Value & Source $^{\mathrm{a}}$ \\
\hline$a_{0}$ & $\mathrm{~kg} / \mathrm{m}^{3}$ & Detachability of original soil & $2 \cdot 10^{3}$ to $9 \cdot 10^{3}$ & $\mathrm{C}$ \\
$a_{d 0}$ & $\mathrm{~kg} / \mathrm{m}^{3}$ & Detachability of deposited sediment & $1 \cdot 10^{5}$ to $5 \cdot 10^{5}$ & $\mathrm{C}$ \\
$F$ & - & Effective fraction of stream power & $0.005-0.0125$ & $\mathrm{C}$ \\
$d_{r}$ & $\mathrm{~m}$ & Raindrop diameter & 0.0003 to 0.0009 & $\mathrm{M}$ \\
$v_{r}$ & $\mathrm{~m} / \mathrm{s}$ & Raindrop velocity & $0.5-4.0$ & $\mathrm{M}$ \\
$m_{t 0}^{*}$ & $\mathrm{~kg} / \mathrm{m}^{2}$ & Deposited mass needed to shield original soil & 3.0 & $\mathrm{~L}$ \\
$n_{0}$ & - & Minimum Manning coefficient & $0.030-0.096$ & $\mathrm{C}$ \\
$\epsilon$ & - & Exponent in friction model & $1 / 3$ & $\mathrm{~L}$ \\
$k_{s}$ & $\mathrm{~mm} / \mathrm{hr}$ & Saturated hydraulic conductivity & $0.5-20$ & $\mathrm{M}$ \\
$h_{f}$ & $\mathrm{~m}$ & Wetting front capillary pressure head & $0.001-0.1$ & $\mathrm{M}$ \\
$\theta_{i}$ & - & Initial volumetric soil moisture & 0.05 & $\mathrm{~L}$ \\
$\theta_{s}$ & - & Volumetric soil moisture at saturation & 0.4 & $\mathrm{~L}$ \\
$\Phi$ & - & Bed sediment porosity & 0.4 & $\mathrm{~L}$ \\
$\Phi_{b e d}$ & Degree & Static angle of friction for sediment & 34 & $\mathrm{M}$ \\
$\Phi_{C}$ & $\mathrm{~Pa}$ & Effective cohesion & 500 & $\mathrm{C}$ \\
\hline
\end{tabular}

${ }^{a}$ The letters $\mathrm{C}, \mathrm{L}$, and $\mathrm{M}$ refer to values determined through calibration, inferred from the literature, and derived from measurements or laboratory analyses of sediment from our study site, respectively.

recorded by the upstream geophone, to differentiate water-dominated flow and debris flow (Figure 4). For more details about monitoring data, we refer to Kean et al. (2019).

\subsection{Model Parameters and Sensitivity Analysis}

Numerical model parameters were estimated using values derived from field measurements, literature searches, laboratory analyses, and calibration (Table 1). Median raindrop diameter and median impact velocity were computed from the disdrometer measurements on 1-min intervals. The saturated hydraulic conductivity $\left(K_{s}\right)$ and wetting front capillary pressure head $\left(h_{f}\right)$ for original soil were derived from field measurements (Figure 2). However, the saturated hydraulic conductivity $\left(K_{s}\right)$ of ravel deposits in the channel, which was not constrained by field measurements, is set to $100 \mathrm{~mm} / \mathrm{hr}$ based on a model calibration. The average thickness of postwildfire ravel deposits within the channel was estimated from field measurements whenever possible. Since measurements were not made prior to each rainstorm, we estimated the ravel deposit thickness based on available prestorm and poststorm measurements (see Table 2). Once ravel deposits were completely eroded within model simulations, we assumed that there was negligible sediment overlying the bedrock channel and, as a consequence, no further erosion could occur in that location. We calibrated the minimum Manning coefficient $\left(n_{0}\right.$, equation (9)) for each storm based on the correlation coefficient between the simulated hydrograph and the actual hydrograph at the basin outlet following Rengers

Table 2

Summary of Rainfall and Sediment Characteristics at the Study Site

\begin{tabular}{|c|c|c|c|c|c|c|c|}
\hline & Date & $\begin{array}{c}I_{15 p} \\
(\mathrm{~mm} / \mathrm{hr})\end{array}$ & $\begin{array}{c}\text { Total rainfall } \\
\text { (mm) }\end{array}$ & $\begin{array}{l}\text { Ravel deposit } \\
\text { thickness }(\mathrm{m})^{\mathrm{a}}\end{array}$ & $\begin{array}{c}\text { Manning } \\
\text { coefficient }\end{array}$ & $\begin{array}{c}\text { Median raindrop } \\
\text { diameter }(\mathrm{m})\end{array}$ & $\begin{array}{c}\text { Raindrop } \\
\text { velocity }(\mathrm{m} / \mathrm{s})\end{array}$ \\
\hline 1 & 16 Dec 2016 & 26.8 & 35.8 & 0.47 & 0.03 & 0.0008 & 3.04 \\
\hline 2 & 24 Dec 2016 & 10.3 & 18.6 & 0.3 & 0.07 & 0.0007 & 2.21 \\
\hline 3 & 9 Jan 2017 & 8.4 & 10.4 & 0.12 & 0.084 & 0.0007 & 2.97 \\
\hline 4 & 11 Jan 2017 & 11.3 & 14.6 & 0.1 & 0.082 & 0.0008 & 2.69 \\
\hline 5 & 12 Jan 2017 & 15.9 & 7.4 & 0.1 & 0.086 & 0.0009 & 3.34 \\
\hline 6 & 20 Jan 2017 & 25.2 & 23.2 & 0.1 & 0.092 & 0.0009 & 2.92 \\
\hline 7 & 18 Feb 2017 & 38.3 & 37.0 & 0.05 & 0.096 & 0.0010 & 2.91 \\
\hline
\end{tabular}

${ }^{\text {a }}$ The ravel deposit thicknesses in events 1, 3, and 7 are based on field measurements, whereas others are estimates. The median raindrop diameter and impact velocity are averaged values based on time series of each storm. 

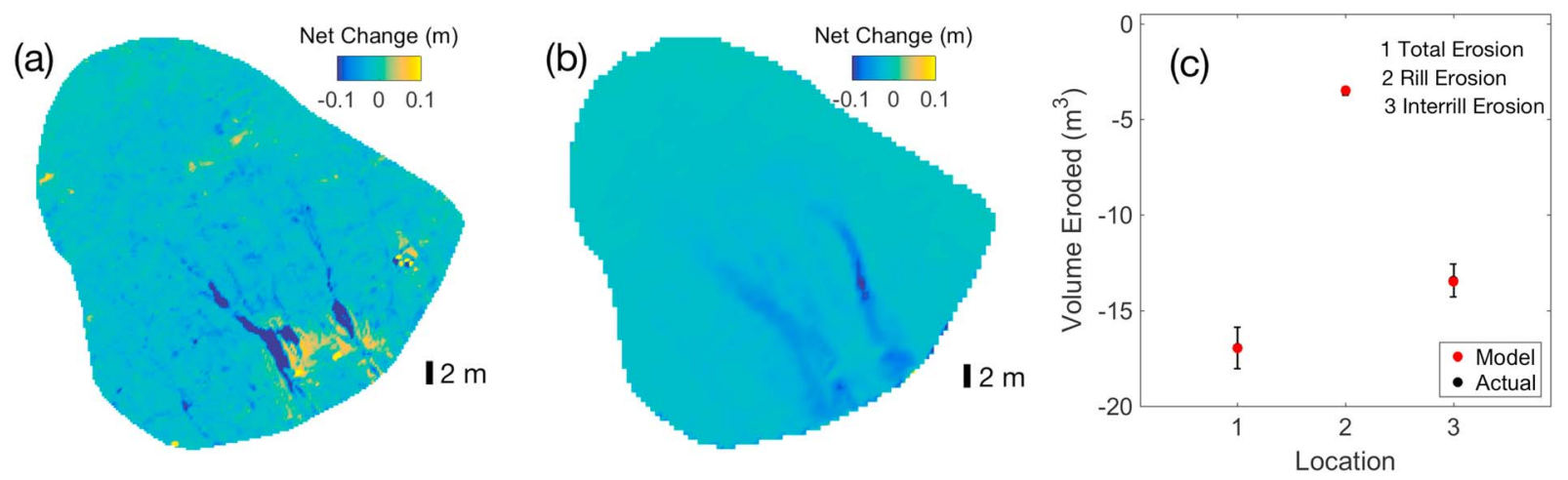

Figure 5. Actual and numerical model simulations of soil erosion on the terrestrial laser scanner (TLS) hillslope using best fit parameters: (a) TLS-derived topographic changes show rill and interrill erosion between the November 2016 and January 2017 surveys. (b and c) A simulation using the best fit parameters results in amounts of rill erosion and interrill erosion between November 2016 and January 2017 that closely match TLS-derived erosion volumes. The measured values and, in some cases, their uncertainties are masked by the symbol for modeled values (red circles in (c)).

et al. (2016). More specifically, we ran a series of simulations with different values of $n_{0}$ and then selected the best fit by maximizing the correlation coefficient between the modeled and actual hydrographs. All model simulations are performed using six particle-size classes with representative grain diameters of $0.001,0.01$, $0.219,2.1,5.0$, and $12.0 \mathrm{~mm}$. Since we have particle-size data associated with postwildfire ravel deposits and hillslopes sediment, the percentage of sediment within each particle-size class varies within the model based on whether or not a pixel is classified as a channel or a hillslope location.

The deposited sediment mass required to completely shield the original soil from erosion $\left(m_{t 0}^{*}\right)$ ranges from 1.5 to $5 \mathrm{~kg} / \mathrm{m}^{2}$ based on flume experiments (Heng et al., 2011). We set $m_{t 0}^{*}$ to an intermediate value of $3 \mathrm{~kg} / \mathrm{m}^{2}$ in all numerical simulations. Three additional parameters in the Hairsine-Rose soil erosion model that represent the effective fraction of stream power $(F)$, the detachability of the original soil $\left(a_{0}\right)$, and the detachability of the deposited soil $\left(a_{d 0}\right)$ also needed to be calibrated. To calibrate these parameters, we carried out a series of numerical experiments with a wide range of the parameter combinations and quantitatively compared the modeled erosion volume with TLS-derived measurements of erosion volume in the subbasin (Figures S3, S4, S5, and S6). By completing this calibration process, we were also able to explore how different sediment transport processes (i.e., flow-driven and raindrop-driven detachment) influenced hillslope erosion based on sediment volumes and, ultimately, debris-flow initiation by including or excluding those processes from subsets of the numerical experiments. It is important to note that the mechanisms that are responsible for driving most of the erosion at our study site may be different from those that mobilize the sediment that ultimately contributes to debris flows. In other words, it may be the case that hillslope erosion contributes to the majority of the sediment eroded during a storm but that does not necessarily imply that the majority of sediment in debris flows comes from the hillslopes.

We calibrated the Hairsine-Rose model parameters based on erosion occurring between the November 2016 and January 2017 scans (Figures 5b and 5c). To facilitate the calibration process, we classified each point in the subbasin into rill and interrill areas (see Figure S13). The best fit parameters were selected based on the model's ability to correctly simulate the measured amount of erosion within both rill and interrill zones. Given either a simulated or actual (i.e., TLS-derived) DEM, rills were identified through a two-step process. First, we used a the steepest descent flow routing algorithm to generate a map of contributing area. All locations with a contributing area greater than a threshold value of $7 \mathrm{~m}^{2}$ were identified as rills. Assuming that locations with a contributing area greater than $7 \mathrm{~m}^{2}$ roughly represented the center of an incised rill, we next sought to determine the location of the rill edges. We searched to the left and right of each rill center point to identify the first pixel encountered where the contour curvature of the surface was negative and where the elevation was greater than that at the rill center. For all storms in January and February 2017, the Hairsine-Rose model parameters are assumed to be the same as those calibrated based on the two December rainstorms. However, we allow the roughness coefficient, $n_{0}$ (based on a model calibration at the basin scale), and saturated hydraulic conductivity, $K_{s}$ (based on field measurements), to vary from storm to storm.

Despite not having poststorm DEMs covering the entire basin, we do have estimates of basin-averaged sediment yields from the $0.2 \mathrm{~km}^{2}$ drainage that contains our $0.12 \mathrm{~km}^{2}$ study basin. The sediment yield from the 

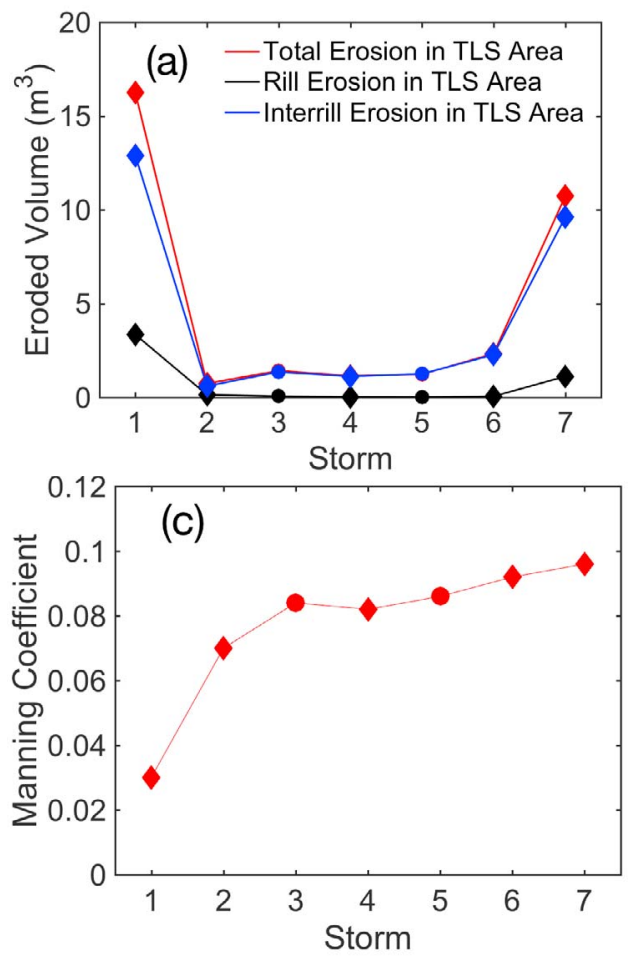
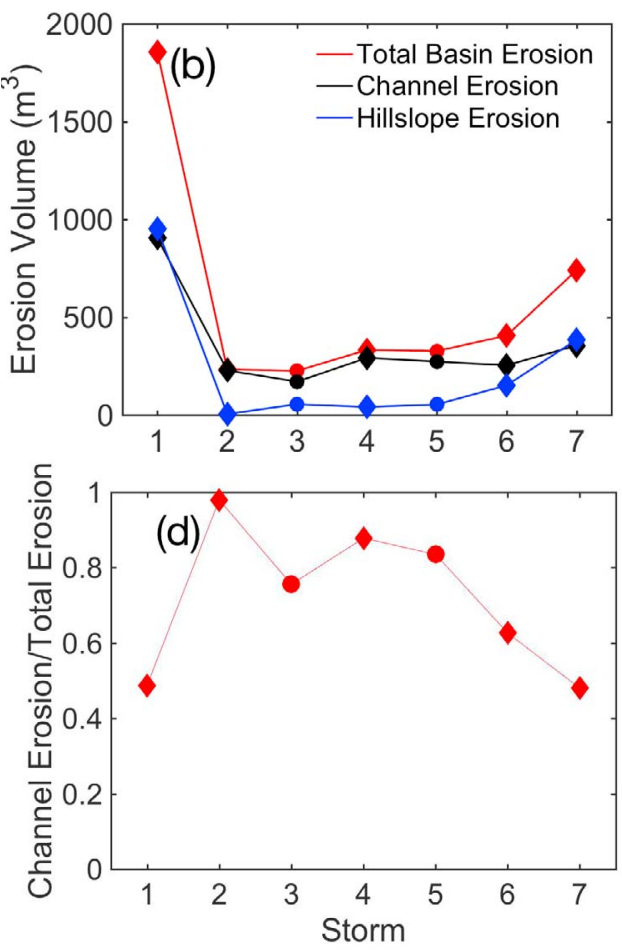

Figure 6. Summary of basin-scale simulations for the 16 December 2016 storm; (a) in some channel locations, periodic mass failures accounted for the removal of more than $0.2 \mathrm{~m}$ of sediment during the storm. (b) Erosion depths are the greatest in the channels, but the total volume of erosion that occurred during the storm on hillslopes is greater than the volume eroded from the channel. (c) There was substantial deposition of sediment in the channel when the model was run without flow-driven detachment processes, but (d) the spatial distribution of erosion simulated without raindrop-driven detachment processes is very similar to the simulation with the best fit parameters (b). (e) Modeled maximum flow depths with best fit parameters (b). (f) Comparisons between the actual (estimated based on the sediment volume in the debris basin in Figure 1a) and modeled sediment yield, including the volume of sediment eroded from hillslopes and channels. Note that the actual erosion volumes from hillslopes and channels are unknown; (g) without flow-driven detachment processes, the modeled erosion volume is substantially less than the actual erosion volume, whereas the difference is less dramatic when only $(\mathrm{h})$ raindrop-driven detachment processes are neglected.

$0.2 \mathrm{~km}^{2}$ basin was obtained for several storms by using prestorm and poststorm estimates of the sediment volume within the Las Lomas debris basin (Staley et al., 2018) located downstream of the channel monitoring station (Figure 1a). Since our study basin composes $60 \%$ of the $0.2 \mathrm{~km}^{2}$ drainage that empties into the debris basin, we estimate the sediment yield from our study area as being $60 \%$ of the total sediment volume within the debris basin. Estimates of the sediment yield are available after the storms on 16 December 2016 and 18 February 2017. These basin-scale estimates of sediment yield serve as a check on the model's performance. Similar to the subbasin simulations, we classified each point in the basin as being within one of two primary domains, either the channel or hillslope, based on a contributing area threshold of $1,000 \mathrm{~m}^{2}$ that was chosen based on field observations of exposed bedrock channels (Figure S1). By classifying points as either the channel or hillslope, we aim to predict the relative importance of different sediment sources in debris-flow initiation process.

\section{Results}

\subsection{Evolution of Ravel Deposit Thickness and Infiltration Capacity}

The presence and thickness of deposits in the channel, which are highly dependent upon erosion from previous rainstorms, acted as a critical sediment source for the debris flows at our site. We use measurements of bed sediment thickness within the channel network to study the changes in channel sediment supply. The thickness of channel deposits significantly decreased after several rainstorms. Field measurements constrain the average thickness of sediment deposits within the channel to be $0.47 \mathrm{~m}$ before the first rainstorm, $0.12 \mathrm{~m}$ prior to the third rainstorm, and $0.05 \mathrm{~m}$ before the last storm (Table 2). Based on the amount of charred 
(a)

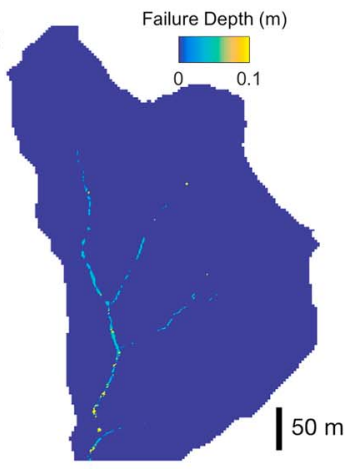

(e)

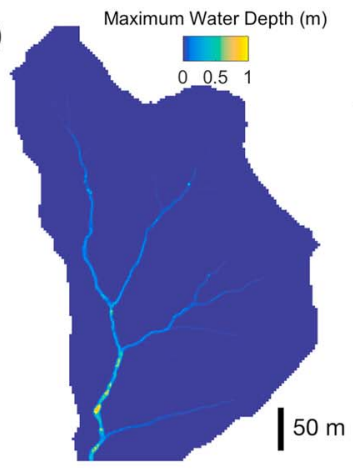

(b)
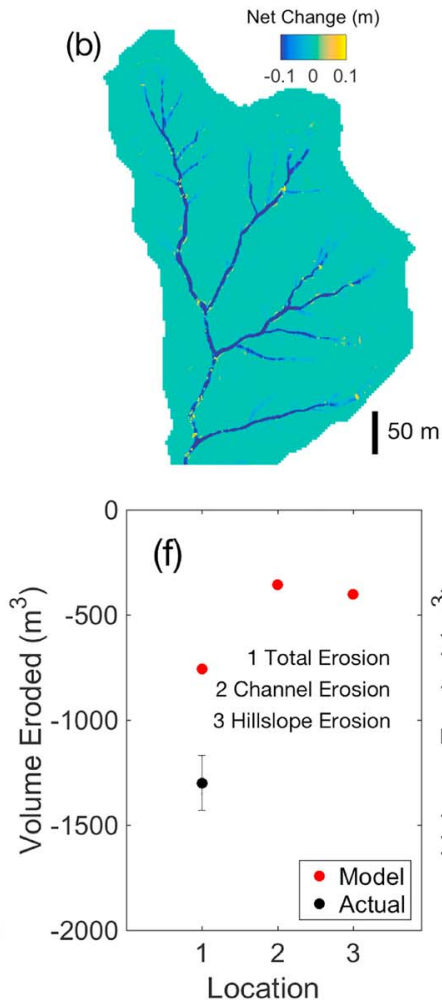

(c)
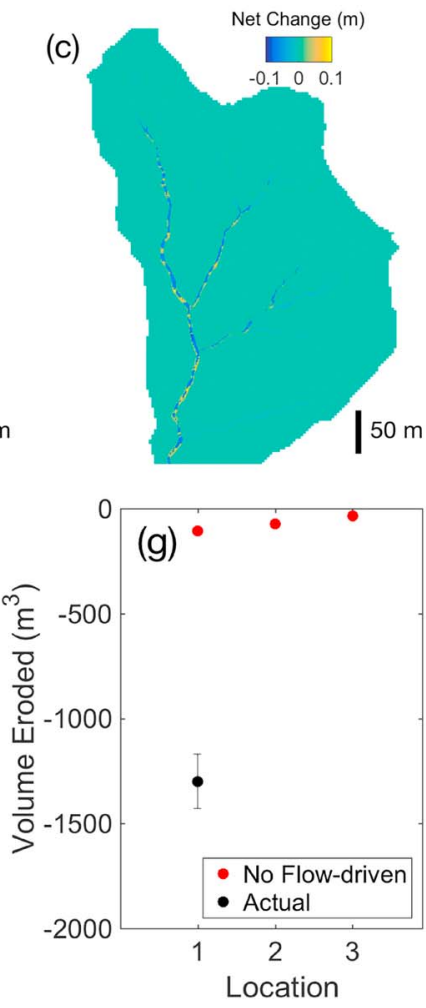

(d)
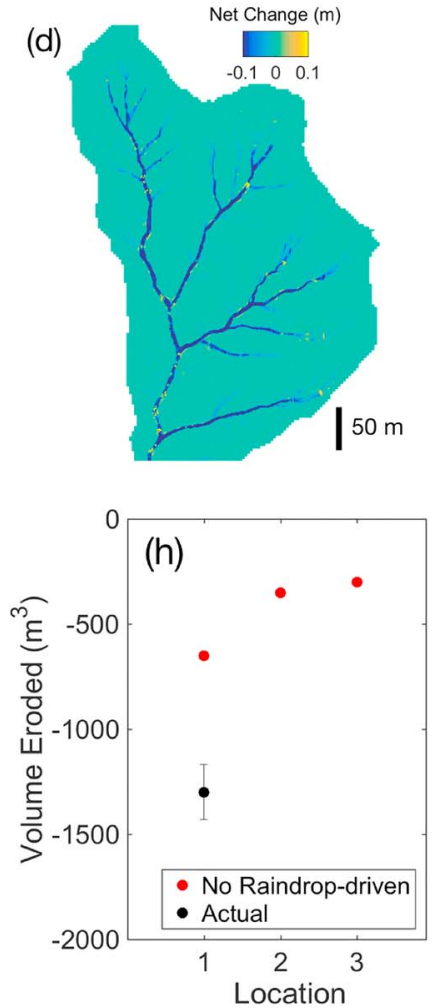

Figure 7. Summary of basin-scale simulations for the 18 February 2017 storm; (a) in most of the channel, bed failure processes were responsible for removing only small amounts of sediment (less than $0.05 \mathrm{~m}$ ) throughout the storm. (b) Erosion depths are greatest in the channels, but the model indicates that (f) substantial erosion occurred on the hillslopes. (c and g) Very limited erosion occurs when flow-driven detachment processes are neglected while (d and $\mathrm{h}$ ) erosion volumes do not change as substantially when only raindrop-driven detachment processes are neglected. (e) Modeled maximum flow depths with best fit parameters (b).

material observed within the deposits, these measurements mainly reflect the depth of postwildfire dry ravel deposits. There was undoubtedly additional sediment within the channel prior to the wildfire, particularly lower in the basin. Our measurements are unlikely to have included this sediment thickness since those older deposits contained numerous large boulders and cobbles that would have refused the rebar.

Infiltration measurements suggest that the saturated hydraulic conductivity $\left(K_{s}\right)$ and wetting front capillary pressure head $\left(h_{f}\right)$ did not change substantially during the study period (Figure 2). The median of $K_{s}$ made during site visits in September and November 2016 was $17 \mathrm{~mm} / \mathrm{hr}$ while the median of all $K_{s}$ measurements made in January 2017 was $19 \mathrm{~mm} / \mathrm{hr}$ (Figures $2 \mathrm{a}$ and 2c). Similarly, median values of wetting front capillary pressure head were approximately 0.005 and $0.013 \mathrm{~m}$ for September-November 2016 and January 2017 (Figures $2 \mathrm{~b}$ and $2 \mathrm{~d}$ ), both of which are small relative to typical unburned values of roughly $0.11 \mathrm{~m}$ for sandy loam soils (Maidment, 1993).

\subsection{Comparisons Between Modeled and Observed Sediment Yields}

Based on the TLS-derived topographic changes (Figure 5a), there was a total of $17.0 \pm 0.72 \mathrm{~m}^{3}$ of erosion during the first two rainstorms over the entire TLS area, with $3.5 \pm 0.04 \mathrm{~m}^{3}$ eroding from the rill area and $13.4 \pm 0.68 \mathrm{~m}^{3}$ eroding from the interrill area (Figures $5 \mathrm{a}$ and $5 \mathrm{c}$ ). The best fit model simulations $\left(a_{0}=\right.$ $7 \times 10^{3} \mathrm{~kg} / \mathrm{m}^{3}, a_{d 0}=3 \times 10^{5} \mathrm{~kg} / \mathrm{m}^{3}$, and $\left.F=0.0075\right)$ result in a total net erosion volume of $17.0 \mathrm{~m}^{3}$, with $3.5 \mathrm{~m}^{3}$ from the rill area and $13.5 \mathrm{~m}^{3}$ from the interrill area (Figures $5 \mathrm{~b}$ and $5 \mathrm{c}$ ).

Simulations over the entire basin during the first storm suggest a sediment yield of $1,854 \mathrm{~m}^{3}$ (Figure 6f). Based on an estimated sediment yield of 3,200 $\mathrm{m}^{3}$ for the same storm (Staley et al., 2018) for the entire area upslope of the Las Lomas debris basin, of which our study area composes $60 \%$, we estimate a total sediment yield for our study area of $1,920 \mathrm{~m}^{3}$ (i.e., $60 \%$ of $3,200 \mathrm{~m}^{3}$ ). Since the modeled sediment yield compares favorably with the sediment yield estimated from the volumetric change within the debris basin, we conclude that the model is adequately simulating erosion volumes during these storms (Figure 6f). Similarly, 

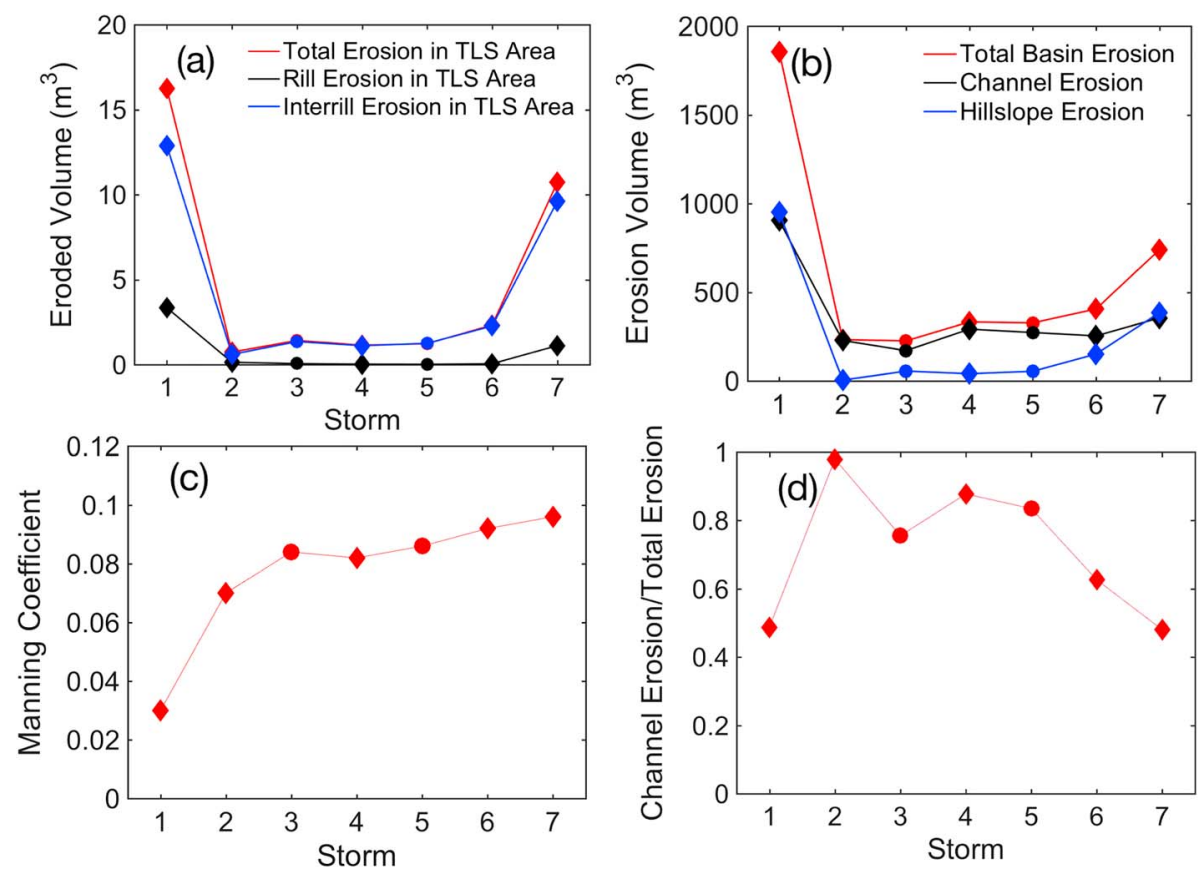

Figure 8. A summary of model results from all seven runoff-producing rainstorms during the monitoring period. Diamond indicates debris-flow-producing storms; circle represents flood-producing storms. (a) Interrill erosion accounts for over 50\% of hillslope erosion in the terrestrial laser scanner (TLS) area throughout all rainstorms based on model results; (b) hillslope erosion and channel erosion contribute approximately the same amount to total sediment yield at the basin scale during storms 1 and 7; (c) the minimum Manning coefficient $\left(n_{0}\right)$ generally increased with each storm following the fire; (d) despite constant decreases in the amount of ravel deposited within the channel following each storm, the percentage of the total sediment yield attributable to channel erosion varied nonmonotonically with time after the fire.

the basin-scale sediment yield resulting from the storm on 18 February 2017 was approximately $60 \%$ of the $2,100 \mathrm{~m}^{3}$ reported by Staley et al. (2018) or $1,260 \mathrm{~m}^{3}$. The model simulation results in a sediment yield of $740 \mathrm{~m}^{3}$, with $52 \%$ of that sediment coming from the hillslope and $48 \%$ coming from the channel (Figures $7 \mathrm{~b}$ and 7f).

\subsection{Comparisons Between Modeled and Observed Hydrographs}

Hydrographs from the 16 December 2016 and 18 February 2017 rainstorms are characterized by intermittent periods of debris-flow activity, which correspond to times when the 15-min average rainfall intensity $\left(I_{15}\right)$ exceeds $15-20 \mathrm{~mm} / \mathrm{hr}$. We identified three distinct periods of debris-flow activity during the first rainstorm on 16 December 2016 based on the video and geophone data (Figure 4a). The modeled hydrograph at the outlet of the basin similarly includes three distinct periods of debris flow during the 16 December 2016 storm (Figures 3a and 4a). The simulated hydrograph varies relatively smoothly during the early stages of the storm and does not contain short-lived spikes in flow depth, which are common in the monitoring data and often associated with the passage of granular-rich debris-flow surges. The simulated stage is, however, highly variable during the last two debris-flow periods with rapid oscillations in flow depth that are associated with pulses of high sediment concentration. The simulated sediment concentration is typically well above $40 \%$, which we roughly associated with the transition from runoff to debris flow, during times corresponding to observed debris flows (Figure 3a). The best fit Manning coefficient for the first storm was $n_{0}=0.03$ (Table 2), likely reflecting the abundance of relatively fine-grained, postwildfire dry ravel deposits within the channel that obscured boulders and reduced roughness.

The observed hydrograph during the storm on 18 February 2017 is also characterized by three periods of debris flow (Figures $3 \mathrm{~b}$ and $4 \mathrm{~b}$ ). However, the model only correctly simulates the first period of debris flow. The best fit Manning coefficient increased systematically with every storm, rising to a value of $n_{0}=0.096$ during the last rainstorm on 18 February 2017 (Table 2). The change in hydraulic roughness mainly reflects a widespread erosion of dry ravel deposits within the channel that led to the excavation of large boulders and cobbles. 

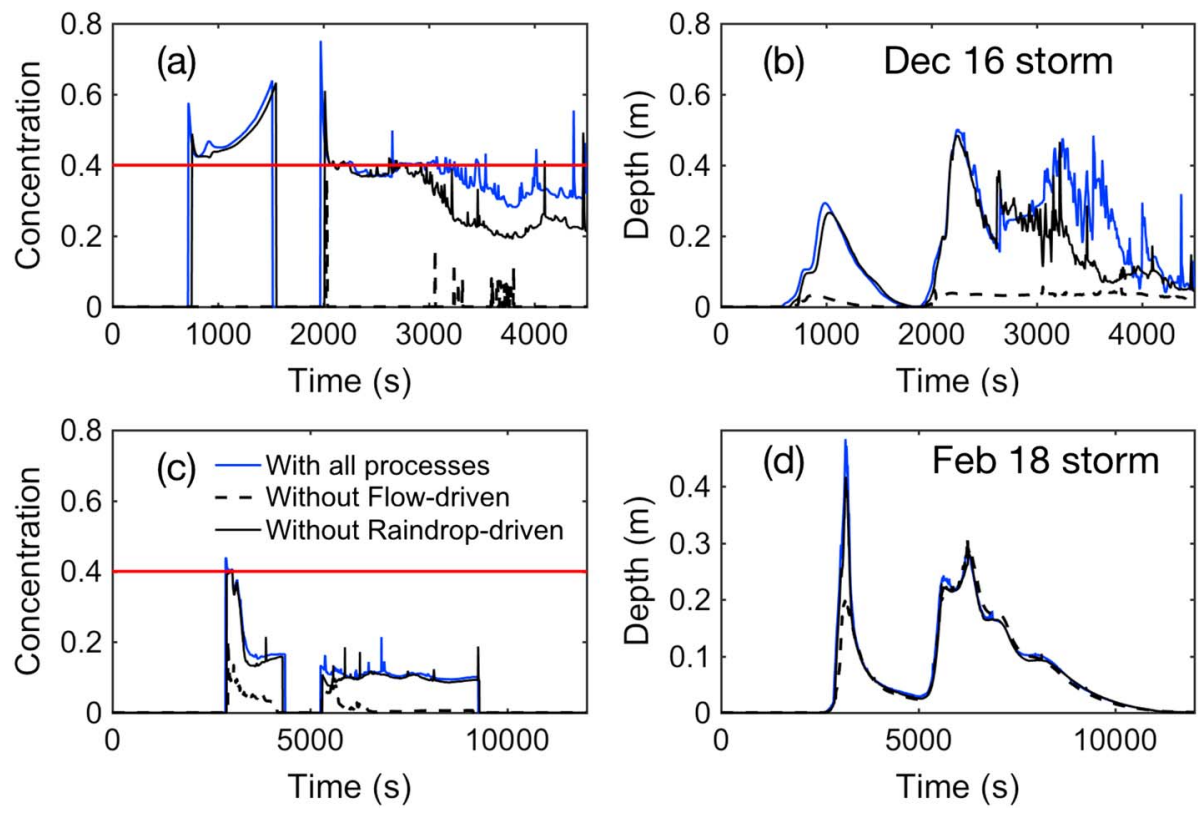

Figure 9. Simulations with and without flow-driven and raindrop-driven detachment processes can be used to fingerprint the sediment contributing to debris flows. Modeled sediment concentrations greater than $40 \%$ (red line) indicate debris-flow activity. (a and c) Simulations produce debris flows during the 16 December 2016 storm and 18 February 2017 storm regardless of whether or not raindrop-driven detachment processes are active but do require flow-driven detachment processes to be active. ( $b$ and d) Lower flow depths in passing lower station appear due to the absence of flow-driven detachment processes in the 16 December 2016 storm and the first debris-flow period in the 18 February 2017 storm.

\subsection{Fingerprinting Debris-Flow Sediment}

Simulations indicate that debris flows initiated during storms where channel incision accounted for the majority of total erosion as well as storms, such as those on 16 December 2016 and 18 February 2018, where hillslopes and channels contributed similarly to the overall sediment yield (Figure 8b). Moreover, interrill erosion appears to have dominated hillslope erosion (Figure 8a) during the two storms where hillslopes contributed more than the channel network to the total basin-scale sediment yield. A more detailed model sensitivity analysis was required to isolate the sediment transport mechanisms through which this sediment was mobilized into debris flows.

The relative importance of raindrop-driven sediment transport, for example, can be assessed by letting $F=0$, which effectively removes all flow-driven detachment processes from the model. Similarly, if we set $e_{k}=0$ and $e_{r k}=0$, which represent the soil and deposited sediment detachment rates due to raindrop impact, we can predict the relative importance of flow-driven detachment processes. When flow-driven processes are neglected (i.e., $F=0$ ), simulations substantially underestimate the total sediment yield for both the 16 December 2016 and 18 February 2017 storms. The impact of raindrop-driven detachment is more evident during the 16 December 2016 storm (Figure 6h) than the 18 February 2017 storm as the model results indicate (Figure $7 \mathrm{~h}$ ). Both raindrop- and flow-driven detachments are needed to accurately simulate the sediment yield for the 16 December 2016 storm.

Despite the importance of both flow-driven and raindrop-driven detachment processes, increases in sediment concentration within the channel network can be attributed in large part to flow-driven sediment detachment (Figure 9). Raindrop-driven processes accounted for only 9\% of the total erosion throughout the entire basin during both storms (Figures 6 and 7). Furthermore, simulations indicate multiple distinct periods of debris-flow activity (i.e., sediment concentrations in excess of $40 \%$ ) regardless of the inclusion of raindrop-driven detachment (Figure 9). In contrast, the model simulates much smaller flow depths with low sediment concentration (and no debris flows) at the monitoring station when flow-driven sediment transport processes are inactive. Lower flow depths result from reduced sediment concentration in the absence of flow-driven detachment processes (Figures 9a and 9b). Simulations further suggest that no debris flow would have formed in the absence of flow-driven detachment processes (Figure 9), meaning 

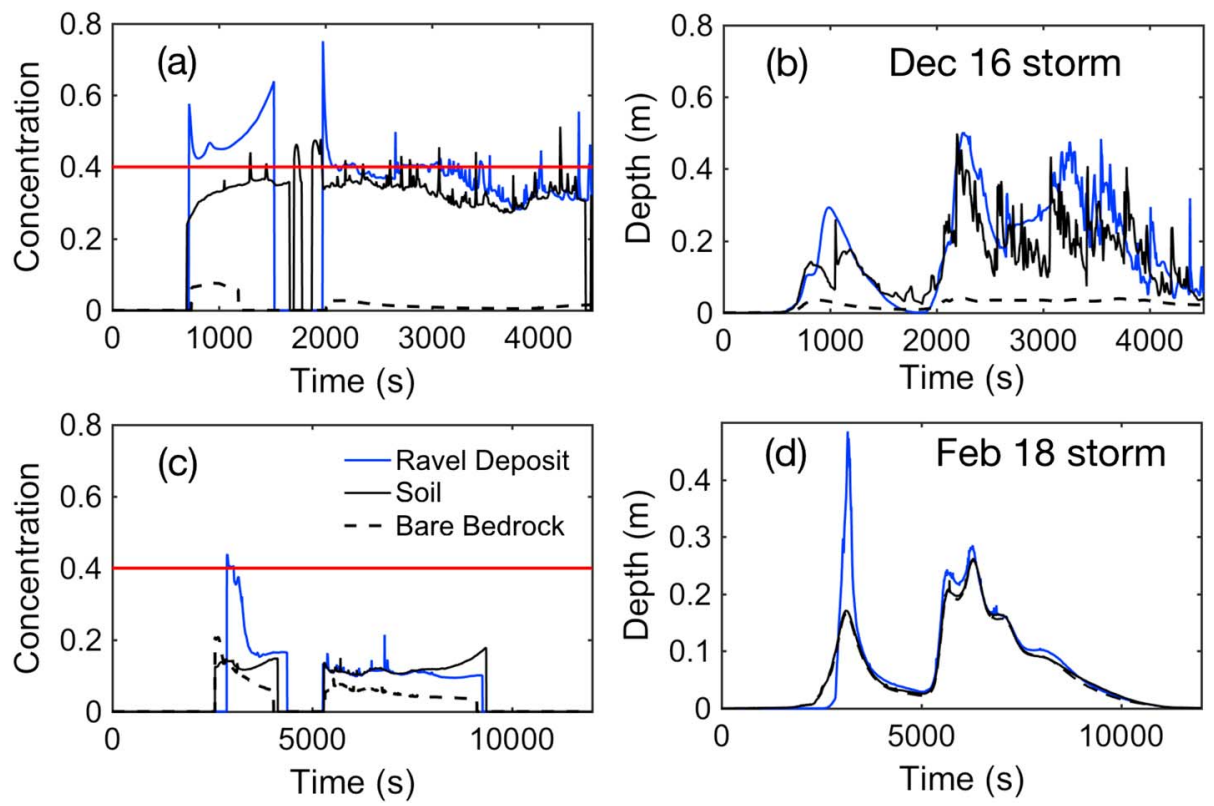

Figure 10. Simulations starting with different initial conditions of channel sediment supply can be used to isolate the importance of sediment sources for debris-flow initiation. Modeled sediment concentrations greater than $40 \%$ (red line) indicate debris-flow activity. ( $a$ and b) Simulations of the 16 December 2016 storm indicate that multiple periods of debris flow would have occurred regardless of whether or not sediment in the channel consisted of more highly erodible ravel deposits or more cohesive soil. No debris flows and very small water depths in passing lower station would have formed if there were no sediment in the channel. (c and d) Simulations of the 18 February 2017 storm suggest that the presence of ravel deposits within the channel directly contributed to sediment concentrations in excess of $40 \%$ during the early phase of the storm. No debris flows form when there is no sediment in the channel or if the channel sediment is made up of a more cohesive soil. But water depths in passing lower station are very similar for all three initial conditions in the last two flow periods (5000s to 10000 s in d).

that process likely played a critical role in the initiation of those debris flows. A simulation that did not include raindrop-driven processes, in contrast, resulted in only minor changes to the simulated sediment concentration, suggesting those processes were less likely to have affected debris-flow initiation (Figures 9a and 9c).

\subsection{Channel Sediment Supply and Debris Flow Initiation}

In addition to providing insight into the mechanisms that mobilize the sediment that ultimately creates debris flows, simulations also reveal information about how the prestorm sediment supply controls debris-flow initiation. By conducting a series of numerical experiments with different types of sediment (e.g., soil or postwildfire dry ravel deposits) in the channel at the start of storm, we explored the importance of different sediment sources in the debris-flow initiation process. During the storm on 16 December 2016, the model simulates several periods of debris flow whether or not the sediment in the channel consists of dry ravel deposits (i.e., more easily erodible deposited sediment) or original soil at the start of storm (Figure 10). Even though we are not allowing mass failure in the original soil, debris flows still can be generated from both the gradual entrainment and/or mass failure due to deposition or re-deposition after erosion during storms. In that case, the model suggests that the difference in erodibility between original soil and deposited sediment (dry ravel) would not be sufficient to determine whether or not debris flows formed. Note that, even though slightly more than half of all sediment eroded during the storm on 16 December 2016 likely came from the hillslopes (Figures $8 \mathrm{~b}$ and $8 \mathrm{~d}$ ), the model does not simulate debris-flow initiation in the case where there is no sediment of any kind in the channel at the start of the storm (Figure 10).

During the storm on 18 February 2017, simulations suggest that no debris flows would have been generated if soil, which we assume has different properties from dry ravel deposits, provided the sole source of sediment in the channel at the start of the storm (Figures 10c and 10d). Further, the model indicates runoff with relatively minor amounts of sediment when the channels are assumed to contain no sediment at the start of the storm (Figures 10c and 10d). There was little dry ravel remaining in the channel at the start of the February storm, but this sediment was perhaps important in setting up the first period of observed debris flow. 

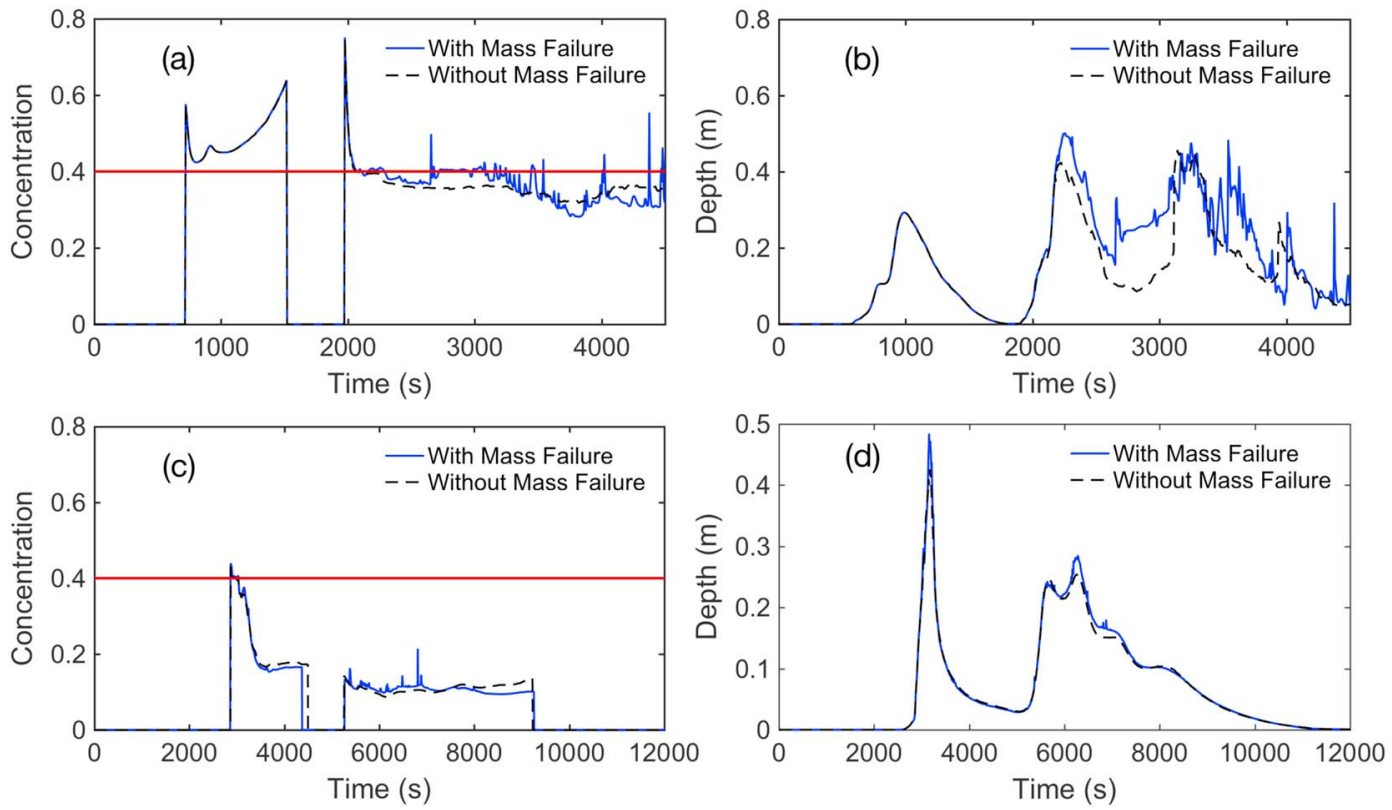

Figure 11. A simulation including bed failure processes during the 16 December 2016 storm results in a large number of debris flows, which are characterized by high sediment concentration exceeding $40 \%$ and rapid increases in flow depth, while simulations without bed failure indicate fewer debris-flow surges, especially during the second half of the storm. Simulations including the bed failure processes during the 18 February 2017 storm are similar to those that do not include bed failure, suggesting that bed failure was not critical for debris-flow initiation during the early phase of that storm. Note that three periods of debris flow were observed during this storm but the model only simulates one period of debris flow.

\subsection{Initiation Mechanism}

One way to assess the importance of the mass failure of bed sediment on debris-flow initiation is to conduct simulations with and without the inclusion of bed failure processes. There are noticeable differences in model simulations that include and do not include mass failure of channel bed sediment during the 16 December 2016 storm. Simulations suggest that the last two periods of observed debris flow would not have occurred in the absence of channel bed failure (Figures 11a and 11b). Sediment concentration is high toward the end of the storm but less than the threshold of $40 \%$ (Figure 11a). We conclude that the mass failure of channel bed sediment was a key mechanism in facilitating the transition from runoff to debris flow during this rainstorm. As expected, the model indicates that bed failure was restricted to the channel network and areas of concentrated flow (Figures $6 a$ and $7 a$ ). To evaluate the importance of channel bed failure during the 18 February 2017 storm, we also carried out a series of simulations with and without bed failure processes. Simulations indicate that the bed failure process was likely not active during the 18 February 2017 storm (Figure 11). There is no substantial change between simulations with and without the inclusion of bed failure as an active process (Figures 11c and 11d). We described the magnitude and frequency of mass failures during these two storms in support information (Figure S10). Based on the occurrence of bed failure during the second half of the storm on 16 December 2016 (Figure S10), some portion of the sediment involved in bed failure events is likely derived from sediment moving through the channel network throughout the course of the storm as opposed to being sourced solely from dry ravel deposits that are present in the channel prior to rainfall.

\section{Discussion}

Aside from the debris-flow and sedimentation hazards that it creates, erosion during the period of disturbance following wildfire may contribute substantially to denudation rates over geologic time (Orem \& Pelletier, 2015) with implications for landscape evolution (Istanbulluoglu et al., 2004; Lavé \& Burbank, 2004). Estimates of hillslope erosion derived here from repeat TLS add to the growing database of studies that utilize high-resolution topographic data (e.g., DeLong et al., 2018; Orem \& Pelletier, 2015; Rengers et al., 2016; Staley et al., 2014; Wester et al., 2014) to quantify the spatial patterns of erosion within a recently 
burned landscape. Likewise, the rainfall records and channel monitoring data provide additional constraints on the precise timing of debris flows within rainstorms, which can be combined with larger data sets of postwildfire debris-flow activity throughout the western United States to improve empirical models used to estimate debris-flow likelihood (Staley et al., 2017). While individual postwildfire studies may frequently be limited in scope (e.g., one hillslope or one drainage basin), when viewed together as a community data set, these studies will help elucidate common trends related to the impact of wildfire on surface processes in different geologic and climate settings and provide additional data for developing and validating empirical models (e.g., Gartner et al., 2014; Wagenbrenner \& Robichaud, 2013). In particular, several studies that utilize repeat TLS surveys to document spatial patterns in erosion have concluded that hillslope sediment, including that mobilized from shallow hillslope erosion, can account for the majority of erosion within small headwater drainage basins (e.g., DeLong et al., 2018; Rengers et al., 2016; Staley et al., 2014). In contrast, we found that channels contributed more to event sediment yields during five of the monitored rainstorms but that hillslopes and channels contributed equally to the sediment yield during the two most intense rainstorms (Figure 8). Despite intense rilling, DEMs of difference derived from repeat TLS surveys at our study site corroborate findings from past studies (e.g., Rengers et al., 2016; Staley et al., 2014), which found that interrill zones may yield more sediment than rills on burned hillslopes (Figure 5c). Small, steep, low-order drainage basins regularly produce debris flows in the Transverse Ranges of southern California after wildfires (Kean et al., 2011), which underscores the need to examine the chain of events beginning with hillslope erosion that lead to debris-flow initiation.

Here, we use a numerical model as a tool to provide insight into the prevalence of different debris-flow initiation mechanisms at our study site, with a particular focus on how the occurrence and style of debris-flow initiation may change due to temporal variations in sediment sources and storm-dependent variations in the sediment detachment processes that move sediment throughout the basin. Distinguishing among different debris-flow initiation mechanisms using field observations alone is complicated by uncertainty in the initiation location of runoff-generated debris flows, which do not leave behind clearly identifiable scarps commonly observed when debris flows mobilize from shallow landslides. Some studies suggest that continuous grain-by-grain sediment bulking processes can generate postwildfire debris flows (Cannon, 2001a; Cannon et al., 2001, 2001b; Meyer \& Wells, 1997) while others (Kean et al., 2013; McGuire et al., 2017) have demonstrated that the mass failure of sediment deposited within the channel network could also form runoff-generated debris flows. It is not possible to attribute debris-flow initiation to one of these two mechanisms based on available field observations alone. However, identifying the prevalence of particular debris-flow initiation mechanisms in different settings could help refine methods for estimating thresholds associated with debris-flow initiation and potentially aid in explaining observed differences in rainfall intensity-duration thresholds for debris flows that are known to exist among different geographic regions (Staley et al., 2017). By designing a series of numerical model experiments (e.g., McGuire et al., 2017), we were able to determine that bed failure processes within the channel were responsible for generating some, but not all, of the observed debris-flow surges (Figure 11).

Modeling suggests that some debris-flow surges occur even in the absence of bed failure processes so that other initiation mechanisms, such as bank failure (Berti \& Simoni, 2005) and grain-by-grain bulking (Cannon, 2001a; Gabet \& Bookter, 2008), are likely to have been responsible for debris-flow initiation. In particular, the model suggests that progressive entrainment could lead to sediment concentrations in excess of $40 \%$ during the initial portion of both the first (16 December 2016) and last (18 February 2017) rainstorms during the study period (Figure 11). We hypothesize that these results are generally representative of debris-flow initiation processes in steep, recently burned catchments throughout the Transverse Ranges of southern California. One potential limitation of our modeling approach is that bed failure processes are restricted to cases where sufficient infiltration has occurred to saturate the bed material. This restriction could be loosened in the future by improving the coupling between infiltration into the channel sediment, surface water flow, and bed stability. Bank failure, which can add large volumes of sediment to the flow over a short time period, is an additional mechanism that could have contributed to debris-flow initiation. Video evidence (see Figure S12), which shows regular slumping of bank sediment, suggests that the channel banks were unstable and potentially prone to failure. The first two periods of debris flow during the storm on 16 December 2016 may have also resulted from the rapid saturation and subsequent failure of ravel deposits in the channel during the early stages of runoff generation. More generally, results suggest that runoff-generated debris flows may be formed by multiple initiation mechanisms in the same storm at 
our study site. The dominant initiation style for debris flows appears to have changed, sometimes within individual storms, as appears to have been the case during the storm on 16 December 2016 (Figure 11).

While this study focuses on an individual drainage basin, the modeling approach employed here could be used in conjunction with measurements of postwildfire infiltration rates reported elsewhere (e.g., Moody et al., 2009; Robichaud, 2000; Robichaud et al., 2016) and vegetation and ground cover characteristics to explore the coupling among hillslope, channel, and debris-flow processes in different postwildfire environments. Many process-based, postwildfire modeling efforts focus on simulating water-dominated flow, but changes in flow rheology (e.g., from water-dominated to debris-dominated) could be critical to understanding how postwildfire sediment pulses move through the fluvial system, with implications for both landscape evolution (e.g., Lavé \& Burbank, 2004) and riparian ecosystem recovery (e.g., Florsheim et al., 2017). Lavé and Burbank (2004), for example, found that basins less than approximately $1 \mathrm{~km}^{2}$ in the Transverse Ranges of southern California tended to produce more sediment following fires relative to larger watersheds. They attributed this difference partly to a change in process dominance from debris flow dominated at smaller drainage areas to predominantly fluvial transport at larger drainage areas. Models capable of routing sediment from hillslopes through the channel network, as a result of the combined effects of debris flow and fluvial erosion, could be used to explain these observations and also help reduce uncertainty in efforts to predict the geomorphic impacts of ongoing changes in wildfire regimes (Sankey et al., 2017).

In this study, we specifically employ the model to fingerprint the sediment that contributed to debris flows throughout the series of rainstorms during the monitoring period. Extensive rill networks are commonly observed in recently burned landscapes, especially following rainstorms that generate sufficient runoff to produce debris flows. Substantial contributions of fine hillslope sediment, through rill erosion, in particular, have been included as components in previously described conceptual models for the initiation of postwildfire debris flows (e.g., Cannon et al., 2001b; Meyer \& Wells, 1997). A rill network formed within our TLS area, but we found that the majority of the erosion within this area could be attributed to interrill zones (Figure 8a). Thus, rill erosion may not be as crucial as previously thought in the debris-flow initiation process. During storms 1 and 7, which yielded the greatest ratio of hillslope erosion to channel erosion (Figure 8b), the majority of hillslope sediment was supplied from interrill areas (Figure 8a). Moreover, initiation of runoff-generated debris flows at our site does not appear to depend strongly on the presence or absence of a significant source of hillslope sediment. There was a debris flow during the second rainstorm even though the model suggests negligible hillslope erosion during that event (Figure 8b). Hillslope erosion was likely less prevalent during the second storm because modest rainfall intensities led to little runoff in areas with a low contributing area. However, there was still a large supply of easily erodible postwildfire ravel deposits within the channel that even modest flow was capable of transporting, which resulted in a debris flow. A debris flow also initiated during the fourth storm despite limited sediment contributions from hillslopes. The relative importance of hillslope and channel sediment in the debris-flow initiation process, however, may depend on differences in grain-size distribution between the hillslope and the channel, which were initially minimized at our site by the predominance of dry ravel deposits in the channel.

An additional benefit of using the model to fingerprint debris-flow sediment is that we can assess sediment sources within the context of both their location within the watershed (rill, interrill, and channel), as well as the detachment processes responsible for mobilizing them. Since the efficiencies of flow-driven and raindrop-driven transport processes will be affected differently by changes in vegetation and soil hydrologic properties, identifying the relative importance of raindrop- and flow-driven detachment is key to understanding how recovery results in changes to the debris-flow response. Although simulations reveal that a large percentage of hillslope erosion (Figure S11) occurs as a result of raindrop-driven and flow-driven processes operating simultaneously, flow-driven processes appeared more important for providing source sediment for debris flows relative to raindrop-driven processes (Figure 9). Simulations of the 16 December 2016 storm result in multiple periods of debris-flow activity, which matches observations, regardless of whether or not raindrop-driven detachment processes are included in the model. In contrast, simulations without flow-driven detachment processes yield only negligible flow depths at the outlet with low sediment concentration (Figures $9 \mathrm{a}$ and $9 \mathrm{~b}$ ). These results demonstrate the significant role of flow-driven sediment detachment processes in generating debris flows during the 16 December 2016 storm. During the last rainstorm on February 18, simulations similarly suggest that no debris flows would have been generated in the absence of flow-driven detachment processes (Figures 9c and 9d). The effectiveness of flow-driven detachment is less sensitive to vegetation cover and more sensitive to changes in soil hydrological properties 
(McGuire et al., 2016). As a result, we expect decreases in debris-flow likelihood with time to correspond more directly with rates of soil recovery (e.g., the change of $K_{s}$ and $h_{f}$ ) at our site rather than vegetation recovery. Cannon et al. (2008) document a $25 \mathrm{~mm} / \mathrm{hr}$ increase in the rainfall intensity-duration thresholds required for debris-flow initiation following 1 year of recovery in burned areas in southern California. Based on the findings from our study area and observed rates of vegetation recovery following wildfires in southern California (Kinoshita \& Hogue, 2011), we hypothesize that this increase predominantly reflects changes in soil properties and sediment supply rather than vegetation recovery.

Regardless of what detachment processes are included in simulations of the final storm for the entire basin, the model underpredicts the basin-scale sediment yield and simulates modest sediment concentrations during the final two observed periods of debris flow during the storm on 18 February 2017 (Figure 3b). Video from the monitoring station, which caught only the first debris-flow surge prior to the onset of darkness, shows there was a substantial amount of gravel- and boulder-sized sediment within the first debris-flow surge (see Video S1). The transport of boulders and coarse gravel is not included within the current model framework, potentially explaining this discrepancy between the model simulations and the observed debris-flow surges. As an additional consequence of neglecting the transport of boulders and coarse gravel, which had become progressively more exposed in the channel over time, it is not unexpected that the model underestimated the total volume eroded during the final storm (Figure 7f). The gradual coarsening of channel sediment is also reflected in the more than threefold increase in the calibrated hydraulic roughness parameter, $n_{0}$, between 16 December 2016 and 18 February 2017 (Figure $8 \mathrm{c}$ ). The channel covered by ravel deposits is hydraulically smoother than a channel with boulders and cobbles that protrude into the flow.

In addition to altering the physical and hydraulic roughness within the channel network, simulations demonstrate that the presence of ravel deposits likely led to increased sediment concentrations relative to levels that would have been achieved in cases where a more cohesive soil occurred within the channel (Figure 10). However, simulations suggest that debris-flow activity would have occurred during the first postfire rainstorm as long as there was sediment available in the channel system (Figure 10a). Furthermore, debris-flow initiation continued throughout January and February even after most of the channel deposits had been eroded. Despite the fact that dry ravel plays a particularly important role in the redistribution of sediment following wildfire in southern California (e.g., Lamb et al., 2011, 2013), model results (Figures 10a and 10b) suggest that postfire debris-flow initiation processes that are active in southern California may not be different from those in regions that experience far less dry ravel activity (e.g., DeLong et al., 2018). Despite changes in channel sediment supply (e.g., dry ravel deposits) and hydraulic roughness, the timing of debris-flow surges was closely linked to the 15-min rainfall intensity (Figure 4). Periods of debris-flow activity generally coincided with periods where the 15-min rainfall intensity approached or exceeded the regional rainfall intensity-duration threshold $(18.6 \mathrm{~mm} / \mathrm{hr}$ ) for postfire debris-flow initiation (Cannon \& DeGraff, 2009; Staley et al., 2014; Figures 4 and Figure S2). These observations suggest that rainfall intensity-duration thresholds for debris flows may be relatively insensitive to changes in sediment supply and hydraulic roughness, at least within the range of values observed here. That being said, sediment supply will certainty limit debris-flow initiation at some point and may have a more notable impact on debris-flow volumes, which are the not the focus of this work.

Kean et al. (2011) observed a transition in flow characteristics at one of their study sites over the course of the winter following the 2009 Station Fire in the San Gabriel Mountains, from a debris-flow-dominated response early in the winter to more fluid-rich flows later in the winter once the channel had eroded to bedrock and saprolite became exposed on the hillslopes. While debris flows continued to initiate throughout the monitoring period at Las Lomas, the flows did become more water dominated with time. While we predominantly use the magnitude of vertical ground velocity recorded by geophones to quantify the timing of debris flows (Figure 4), characteristics of the ground velocity and stage data also indicate changes in flow behavior. The channel was initially lined with a relatively thick layer of dry ravel deposits that was progressively eroded over time. Ravel deposits within the channel substantially increased the sediment concentration of runoff at the basin outlet during the early stages of the first storm on 16 December 2016 (Figure 3a). During this time, the observed hydrograph at the lower monitoring station is characterized by a number of small roll waves (Figure 3a). Roll waves are different from typical debris-flow surges and are known to result from a hydrodynamic instability in both Newtonian and non-Newtonian fluids (Trowbridge, 1987; Wang, 2002), including viscous slurries formed at high sediment concentrations. We hypothesize that the roll waves developed solely during the initial phases of the first storm due to the formation of a viscous slurry facilitated by 
the abundance of relatively fine-grained ravel deposits within the channel at that time. This period of roll waves was followed by three pulses of debris-flow activity (Figure 4a), each of which contained a number of distinct surges (Figure 3a). In contrast, the last period of debris-flow activity, which occurred during the rainstorm on 18 February 2018, consisted of a single debris-flow surge that lagged slightly behind a more water-dominated pulse of runoff (Figures 3 and S15). These temporal changes in flow characteristics are consistent with past work in the Transverse Ranges that document geomorphic responses to sequences of rainstorms throughout the first postfire year (e.g., Kean et al., 2011; Wells \& Wade, 1987). Wells and Wade (1987), in a study of postwildfire debris flows in the San Dimas Experimental Forest in southern California, observed an absence of new debris-flow deposits following storms that happened later in the first winter after a prescribed fire. Wells and Wade (1987) attributed this shift to decreases in sediment supply but lacked the detailed data needed to test that hypothesis. We continued to observe debris flows throughout the monitoring period, but there appears to be a decrease in the number of surges associated with periods of debris-flow activity (Figure 3) from the first to the last storm, and we attribute this trend to changes in sediment supply. The amplitude and frequency characteristics of the ground motion as recorded by our geophones may hold additional information about flow speed, width, and location (Abancó et al., 2014) and have the potential to be used as a tool for estimating entrainment of bed material (Kean et al., 2015), but such analyses are beyond the scope of our current study.

The factors that remained relatively constant throughout our study at Las Lomas included vegetation cover, which remained minimal, and soil hydrologic properties. Wildfire-induced changes to vegetation and soil, which include reduced interception and lower infiltration capacity, both influence how rainfall is partitioned into runoff. These results are consistent with the idea that debris-flow initiation can be associated with a hydrologic threshold (e.g., Gregoretti \& Fontana, 2008) that is more strongly influenced by changes in rainfall-runoff partitioning than changes in sediment supply. Tracking debris-flow activity along with changes in sediment supply, soil hydrologic properties, and vegetation recovery is a first step toward quantifying the role of each factor in observed temporal changes in postwildfire debris-flow thresholds (e.g., Cannon et al., 2008).

\section{Conclusion}

In this study, we combined repeat TLS and hydrologic monitoring data with a numerical model to examine the sediment sources, sediment transport processes, and initiation mechanisms of postwildfire debris flows within a burned drainage basin in the San Gabriel Mountains, California, USA. Model results provide a detailed reconstruction of both the physical location of debris-flow sediment sources and the transport mechanisms responsible for mobilizing that sediment. By comparing simulated erosion with TLS-derived estimates of topographic change within a subbasin at our study site, we were able to calibrate a process-based sediment transport model and assess the relative importance of raindrop-driven and flow-driven sediment transport processes on debris-flow initiation. With the help of the numerical model, we conclude that both flow- and raindrop-driven sediment transport processes make substantial contributions to erosion in our study area but that sediment derived from the flow-driven detachment processes is critical for debris-flow initiation. Since sediment in channels is detached by flow-driven processes, this result is consistent with past studies (e.g., Moody \& Kinner, 2006; Santi et al., 2008) that have emphasized the importance of channel sediment in generating postwildfire debris flows. Simulations indicate that both the gradual entrainment of sediment and the mass failure of sediment deposited within the channel appear capable of producing runoff with sediment concentrations that are typical of debris flows. The sources of eroded sediment also changed from storm to storm. Debris flows formed during storms where roughly half of the sediment yield can be attributed to hillslope erosion as well as storms where negligible hillslope erosion occurred, suggesting that large inputs of sediment from rill and gully networks during the debris-flow-producing storm are not essential for debris flow initiation. This does not exclude the possibility that rill and gully networks replenish channels with additional sediment through time, which may then promote debris flow initiation during later storms. Despite temporal changes in sediment source and initiation style at our site, debris-flow initiation appears to have remained closely linked with the same 15-min rainfall intensity-duration threshold throughout the study period. While sediment supply undoubtedly plays a role in debris-flow initiation, we conclude that the factors most likely to influence temporal changes in debris-flow likelihood following wildfire are soil-hydrologic factors that influence the partitioning of rainfall into runoff. 


\section{Acknowledgments}

We thank the Editor John Buffington, one anonymous reviewer, and Jen Pierce for helpful comments that improved the quality of the manuscript. This work was partially supported by the U.S. Geological Survey (USGS) Landslide Hazards Program. Any use of trade, product, or firm names in this paper is for descriptive purposes only and does not constitute endorsement by the U.S. Geological Survey. Code for the numerical model is stored in the Community Surface Dynamics Modeling System (CSDMS) model repository at https://csdms.colorado. edu/wiki/Model:SWEHR. Data used in this manuscript are stored in the USGS ScienceBase archive at https://doi.org/ 10.5066/P92HVD2T and https://doi. org/10.5066/P9F3YTBP.

\section{References}

Abancó, C., Hürlimann, M., \& Moya, J. (2014). Analysis of the ground vibration generated by debris flows and other torrential processes at the rebaixader monitoring site (Central Pyrenees, Spain). Natural Hazards and Earth System Sciences, 14(4), 929-943.

Arattano, M., \& Marchi, L. (2000). Video-derived velocity disribution along a debris flow surge. Physics and Chemistry of the Earth, Part B: Hydrology, Oceans and Atmosphere, 25(9), 781-784.

Arattano, M., \& Marchi, L. (2005). Measurements of debris flow velocity through cross-correlation of instrumentation data. Natural Hazards and Earth System Sciences, 5(1), 137-142.

Berti, M., \& Simoni, A. (2005). Experimental evidences and numerical modelling of debris flow initiated by channel runoff. Landslides, 2(3), 171-182. https://doi.org/10.1007/s10346-005-0062-4

Cannon, S. H. (2001a). Debris-flow generation from recently burned watersheds. Environmental and Engineering Geoscience, 7(4), 321. https://doi.org/10.2113/gseegeosci.7.4.321

Cannon, S. H., Bigio, E. R., \& Mine, E. (2001b). A process for fire-related debris flow initiation, Cerro Grande fire, New Mexico. Hydrological Processes, 15(15), 3011-3023. https://doi.org/10.1002/hyp.388

Cannon, S. H., \& DeGraff, J. (2009). The increasing wildfire and post-fire debris-flow threat in Western USA, and implications for consequences of climate change, (First). In K. Sassa, \& P. Canuti (Eds.), Landslides-Disaster risk reduction (pp. 177-190). Berlin, Heidelberg: Springer Berlin Heidelberg. https://doi.org/10.1007/978-3-540-69970-5_9

Cannon, S. H., Gartner, J. E., Wilson, R. C., Bowers, J. C., \& Laber, J. L. (2008). Storm rainfall conditions for floods and debris flows from recently burned areas in southwestern Colorado and southern California. Geomorphology, 96(3-4), 250-269.

Cannon, S. H., Kirkham, R. M., \& Parise, M. (2001). Wildfire-related debris-flow initiation processes, Storm King Mountain, Colorado. Geomorphology, 39(3), 171-188.

DeLong, S. B., Youberg, A. M., DeLong, W. M., \& Murphy, B. P. (2018). Post-wildfire landscape change and erosional processes from repeat terrestrial lidar in a steep headwater catchment, Chiricahua Mountains, Arizona, USA. Geomorphology, 300, 13-30.

DiBiase, R. A., Lamb, M. P., Ganti, V., \& Booth, A. M. (2017). Slope, grain size, and roughness controls on dry sediment transport and storage on steep hillslopes. Journal of Geophysical Research: Earth Surface, 122, 941-960. https://doi.org/10.1002/2016JF003970

Ebel, B. A., \& Moody, J. A. (2017). Synthesis of soil-hydraulic properties and infiltration timescales in wildfire-affected soils. Hydrological Processes, 31(2), 324-340. HYP-16-0392.R1.

Ferguson, R. I. (2012). River channel slope, flow resistance, and gravel entrainment thresholds. Water Resources Research, 48 , W05517. https://doi.org/10.1029/2011WR010850

Florsheim, J. L., Chin, A., Kinoshita, A. M., \& Nourbakhshbeidokhti, S. (2017). Effect of storms during drought on post-wildfire recovery of channel sediment dynamics and habitat in the southern California chaparral, USA. Earth Surface Processes and Landforms, 42(10), 1482-1492.

Florsheim, J. L., Keller, E. A., \& Best, D. W. (1991). Fluvial sediment transport in response to moderate storm flows following chaparral wildfire, Ventura County, southern California. GSA Bulletin, 103(4), 504. https://doi.org/10.1130/0016-7606(1991)103<0504:FSTIRT> 2.3.CO;2

Gabet, E. J., \& Bookter, A. (2008). A morphometric analysis of gullies scoured by post-fire progressively bulked debris flows in southwest Montana, USA. Geomorphology, 96(3), 298-309.

Gabet, E. J., \& Mudd, S. M. (2006). The mobilization of debris flows from shallow landslides. Geomorphology, 74(1), 207-218.

Gartner, J. E., Cannon, S. H., \& Santi, P. M. (2014). Empirical models for predicting volumes of sediment deposited by debris flows and sediment-laden floods in the transverse ranges of southern California. Engineering Geology, 176, 45-56.

Germer, K., \& Braun, J. (2011). Effects of saturation on slope stability: Laboratory experiments utilizing external load. Vadose Zone Journal, $10(2), 477-486$

Green, H. W., \& Ampt, G. (1911). The flow of air and water through soils. Journal of Agriculture Science, 4(1), 1-24.

Gregoretti, C., \& Fontana, G. D. (2008). The triggering of debris flow due to channel-bed failure in some alpine headwater basins of the Dolomites: Analyses of critical runoff. Hydrological Processes, 22(13), 2248-2263. https://doi.org/10.1002/hyp.6821

Hairsine, P. B., \& Rose, C. W. (1991). Rainfall detachment and deposition: Sediment transport in the absence of flow-driven processes. Soil Science Society of America journal, 55(2), 320-324.

Hairsine, P. B., \& Rose, C. W. (1992a). Modeling water erosion due to overland flow using physical principles: 1 . Sheet flow. Water Resources Research, 28(1), 237-243. https://doi.org/10.1029/91WR02380

Hairsine, P. B., \& Rose, C. W. (1992b). Modeling water erosion due to overland flow using physical principles: 2. Rill flow. Water Resources Research, 28(1), 245-250. https://doi.org/10.1029/91WR02381

Heng, B. C. P., Sander, G. C., Armstrong, A., Quinton, J. N., Chandler, J. H., \& Scott, C. F. (2011). Modeling the dynamics of soil erosion and size-selective sediment transport over nonuniform topography in flume-scale experiments. Water Resources Research, 47, W02513. https://doi.org/10.1029/2010WR009375

Istanbulluoglu, E., Tarboton, D. G., Pack, R. T., \& Luce, C. (2003). A sediment transport model for incision of gullies on steep topography. Water Resources Research, 39(4), 1103. https://doi.org/10.1029/2002WR001467

Istanbulluoglu, E., Tarboton, D. G., Pack, R. T., \& Luce, C. H. (2004). Modeling of the interactions between forest vegetation, disturbances, and sediment yields. Journal of Geophysical Research, 109, F01009. https://doi.org/10.1029/2003JF000041

Iverson, R. M., \& Denlinger, R. P. (2001). Flow of variably fluidized granular masses across three-dimensional terrain: 1 . Coulomb mixture theory. Journal of Geophysical Research, 106(B1), 537-552. https://doi.org/10.1029/2000JB900329

Iverson, R. M., Reid, M. E., \& LaHusen, R. G. (1997). Debris-flow mobilization from landslides. Annual Review of Earth and Planetary Sciences, 25(1), 85-138. https://doi.org/10.1146/annurev.earth.25.1.85

Jain, M. K., Kothyari, U. C., \& Raju, K. G. (2005). GIS based distributed model for soil erosion and rate of sediment outflow from catchments. Journal of Hydraulic Engineering, 131(9), 755-769.

Kean, J. W., Coe, J. A., Coviello, V., Smith, J. B., McCoy, S., \& Arattano, M. (2015). Estimating rates of debris flow entrainment from ground vibrations. Geophysical Research Letters, 42, 6365-6372. https://doi.org/10.1002/2015GL064811

Kean, J. W., McCoy, S. W., Tucker, G. E., Staley, D. M., \& Coe, J. A. (2013). Runoff-generated debris flows: Observations and modeling of surge initiation, magnitude, and frequency. Journal of Geophysical Research: Earth Surface, 118, 2190-2207. https://doi.org/10.1002/jgrf 20148

Kean, J. W., Smith, J. B., Rengers, F. K., McGuire, L. A., \& Staley, D. M. (2019). Post-wildfire debris-flow monitoring data, Las Lomas, 2016 Fish Fire, Los Angeles County, California, November 2016 to February 2017. U.S. Geological Survey data release, https://doi.org/10. 5066/P9F3YTBP 
Kean, J. W., Staley, D. M., \& Cannon, S. H. (2011). In situ measurements of post-fire debris flows in southern California: Comparisons of the timing and magnitude of 24 debris-flow events with rainfall and soil moisture conditions. Journal of Geophysical Research, 116, F04019. https://doi.org/10.1029/2011JF002005

Kinoshita, A. M., \& Hogue, T. S. (2011). Spatial and temporal controls on post-fire hydrologic recovery in Southern California watersheds. CATENA, 87(2), 240-252

Lamb, M. P., Levina, M., DiBiase, R. A., \& Fuller, B. M. (2013). Sediment storage by vegetation in steep bedrock landscapes: Theory, experiments, and implications for postfire sediment yield. Journal of Geophysical Research: Earth Surface, 118, 1147-1160. https://doi. org/10.1002/jgrf.20058

Lamb, M. P., Scheingross, J. S., Amidon, W. H., Swanson, E., \& Limaye, A. (2011). A model for fire-induced sediment yield by dry ravel in steep landscapes. Journal of Geophysical Research, 116, F03006. https://doi.org/10.1029/2010JF001878

Langhans, C., Nyman, P., Noske, P. J., Van der Sant, R. E., Lane, P. N. J., \& Sheridan, G. J. (2017). Post-fire hillslope debris flows: Evidence of a distinct erosion process. Geomorphology, 295, 55-75.

Lavé, J, \& Burbank, D. (2004). Denudation processes and rates in the Transverse Ranges, southern California: Erosional response of a transitional landscape to external and anthropogenic forcing. Journal of Geophysical Research, 109, F01006. https://doi.org/10.1029/ 2003JF000023

Maidment, D. R. (1993). Handbook of hydrology (Vol. 1). New York: McGraw-Hill.

McGuire, L. A., Kean, J. W., Staley, D. M., Rengers, F. K., \& Wasklewicz, T. A. (2016). Constraining the relative importance of raindrop- and flow-driven sediment transport mechanisms in postwildfire environments and implications for recovery time scales. Journal of Geophysical Research: Earth Surface, 121, 2211-2237. https://doi.org/10.1002/2016JF003867

McGuire, L. A., \& Rengers, F. K. (2019). Las Lomas Hillside Lidar:. U.S. Geological Survey data release, https://doi.org/10.5066/P92HVD2T

McGuire, L. A., Rengers, F. K., Kean, J. W., \& Staley, D. M. (2017). Debris flow initiation by runoff in a recently burned basin: Is grain-by-grain sediment bulking or en masse failure to blame? Geophysical Research Letters, 44, 7310-7319. https://doi.org/10.1002/ 2017GL074243

Melis, T. S., Webb, R. H., Griffiths, P., \& Wise, T. (1994). Magnitude and frequency data for historic debris flows in Grand Canyon National Park and vicinity, Arizona. U.S. Geological Survey Water-Resources Investigations Report, 94-4214 pp. 285.

Meyer, G. A., \& Wells, S. G. (1997). Fire-related sedimentation events on alluvial fans, Yellowstone National Park, U.S.A. Journal of Sedimentary Research, 67(5), 776. https://doi.org/10.1306/D426863A-2B26-11D7-8648000102C1865D

Moody, J., \& Kinner, D. (2006). Spatial structures of stream and hillslope drainage networks following gully erosion after wildfire. Earth Surface Processes and Landforms, 31(3), 319-337. https://doi.org/10.1002/esp.1246

Moody, J. A., Kinner, D. A., \& Úbeda, X. (2009). Linking hydraulic properties of fire-affected soils to infiltration and water repellency. Journal of Hydrology, 379(3-4), 291-303.

Moody, J. A., \& Martin, D. A. (2009). Synthesis of sediment yields after wildland fire in differen rainfall regimes in the western United States. International Journal of Wildland Fire, 18(1), 96-115.

Moody, J. A., Smith, J. D., \& Ragan, B. W. (2005). Critical shear stress for erosion of cohesive soils subjected to temperatures typical of wildfires. Journal of Geophysical Research, 110, F01004. https://doi.org/10.1029/2004JF000141

Nyman, P., Sheridan, G. J., Smith, H. G., \& Lane, P. N. J. (2011). Evidence of debris flow occurrence after wildfire in upland catchments of south-east Australia. Geomorphology, 125(3), 383-401.

Orem, C. A., \& Pelletier, J. D. (2015). Quantifying the time scale of elevated geomorphic response following wildfires using multi-temporal LiDAR data: An example from the Las Conchas fire, Jemez Mountains, New Mexico. Geomorphology, 232, $224-238$.

Rengers, F. K., McGuire, L. A., Kean, J. W., Staley, D. M., \& Hobley, D. E. J. (2016). Model simulations of flood and debris flow timing in steep catchments after wildfire. Water Resources Research, 52, 6041-6061. https://doi.org/10.1002/2015WR018176

Rengers, F. K., Tucker, G. E., Moody, J. A., \& Ebel, B. A. (2016). Illuminating wildfire erosion and deposition patterns with repeat terrestrial lidar. Journal of Geophysical Research: Earth Surface, 121, 588-608. https://doi.org/10.1002/2015JF003600

Robichaud, P. R. (2000). Fire effects on infiltration rates after prescribed fire in Northern Rocky Mountain forests, USA. Journal of Hydrology, 231, 220-229.

Robichaud, Wagenbrenner, J. W., \& Brown, R. E. (2010). Rill erosion in natural and disturbed forests: 1. Measurements. Water Resources Research, 46, W10506. https://doi.org/10.1029/2009WR008314

Robichaud, P. R., Wagenbrenner, J. W., Pierson, F. B., Spaeth, K. E., Ashmun, L. E., \& Moffet, C. A. (2016). Infiltration and interrill erosion rates after a wildfire in western Montana, USA. Catena, 142, 77-88.

Roering, J. J., \& Gerber, M. (2005). Fire and the evolution of steep, soil-mantled landscapes. Geology, 33(5), 349. https://doi.org/10.1130/ G21260.1

Sankey, J. B., Kreitler, J., Hawbaker, T. J., McVay, J. L., Miller, M. E., Mueller, E. R., et al. (2017). Climate, wildfire, and erosion ensemble foretells more sediment in western USA watersheds. Geophysical Research Letters, 44, 8884-8892. https://doi.org/10.1002/2017GL073979

Santi, P. M., deWolfe, V. G., Higgins, J. D., Cannon, S. H., \& Gartner, J. E. (2008). Sources of debris flow material in burned areas Geomorphology, 96(3), 310-321.

Schmidt, K. M., Hanshaw, M., Howle, J. F., Kean, J. W., Staley, D. M., Stock, J. D., \& Bawden, G. W. (2011). Hydrologic conditions and terrestrial laser scanning of post-fire debris flows in the San Gabriel Mountains, CA, USA. In Proceedings of the fifth international conference on debris flow hazards mitigation/mechanics, prediction, and assessment, padua, italy (pp. 583-593).

Shakesby, R. A., \& Doerr, S. H. (2006). Wildfire as a hydrological and geomorphological agent. Earth-Science Reviews, 74(3), $269-307$.

Smith, H. G., Sheridan, G. J., Nyman, P., Child, D. P., Lane, P. N. J., Hotchkis, M. A. C., \& Jacobsen, G. E. (2012). Quantifying sources of fine sediment supplied to post-fire debris flows using fallout radionuclide tracers. Geomorphology, 139-140, 403-415.

Staley, D. M., Negri, J. A., Kean, J. W., Laber, J. L., Tillery, A. C., \& Youberg, A. M. (2017). Prediction of spatially explicit rainfall intensity-duration thresholds for post-fire debris-flow generation in the western United States. Geomorphology, 278, 149-162.

Staley, D. M., Tillery, A. C., Kean, J. W., McGuire, L. A., Pauling, H. E., Rengers, F. K., \& Smith, J. B. (2018). Estimating post-fire debris-flow hazards prior to wildfire using a statistical analysis of historical distributions of fire severity from remote sensing data. International Journal of Wildland Fire, 27(9), 595-608.

Staley, D. M., Wasklewicz, T. A., \& Kean, J. W. (2014). Characterizing the primary material sources and dominant erosional processes for post-fire debris-flow initiation in a headwater basin using multi-temporal terrestrial laser scanning data. Geomorphology, 214, 324-338.

Suwa, H., Okano, K., \& Kanno, T. (2009). Behavior of debris flows monitored on test slopes of Kamikamihorizawa Creek, Mount Yakedake, Japan. International Journal of Erosion Control Engineering, 2(2), 33-45.

Takahashi, T. (1978). Mechanical characteristics of debris flow. Journal of the Hydraulics Division, 104(8), 1153-1169.

Takahashi, T. (1981). Debris flow. Annual Review of Fluid Mechanics, 13(1), 57-77. 
Trowbridge, J. (1987). Instability of concentrated free surface flows. Journal of Geophysical Research, 92(C9), 9523-9530. https://doi.org/ 10.1029/JC092iC09p09523

Vandervaere, J.-P., Vauclin, M., \& Elrick, D. E. (2000). Transient flow from tension infiltrometers I. the two-parameter equation. Soil Science Society of America journal, 64, 1263-1272.

Wagenbrenner, J., \& Robichaud, P. (2013). Post-fire bedload sediment delivery across spatial scales in the interior western United States. Earth Surface Processes and Landforms, 39(7), 865-876. https://doi.org/10.1002/esp.3488

Wang, Z.-Y. (2002). Free surface instability of non-newtonian laminar flows. Journal of Hydraulic Research, 40(4), 449-460. https://doi.org/ $10.1080 / 00221680209499887$

Wells, I., \& Wade, G. (1987). The effects of fire on the generation of debris flows in southern California. In Debris Flows/Avalanches, Geological Society of America. https://doi.org/10.1130/REG7-p105

Wester, T., Wasklewicz, T., \& Staley, D. (2014). Functional and structural connectivity within a recently burned drainage basin. Geomorphology, 206, 362-373.

Westerling, A. L., Hidalgo, H. G., Cayan, D. R., \& Swetnam, T. W. (2006). Warming and earlier spring increase Western U.S. forest wildfire activity. Science, 313(5789), 940-943.

Zhang, R. (1997). Determination of soil sorptivity and hydraulic conductivity from the disk infiltrometer. Soil Science Society of America, $61,1024-1030$. 